Prepared for the U.S. Department of Energy under Contract DE-AC05-76RL01830

\title{
Field-Derived Hydraulic Properties for Perched-Water Aquifer Wells 299-E33-350 and 299-E33-351, Hanford Site B-Complex Area
}

\author{
DR Newcomer
}

July 2014

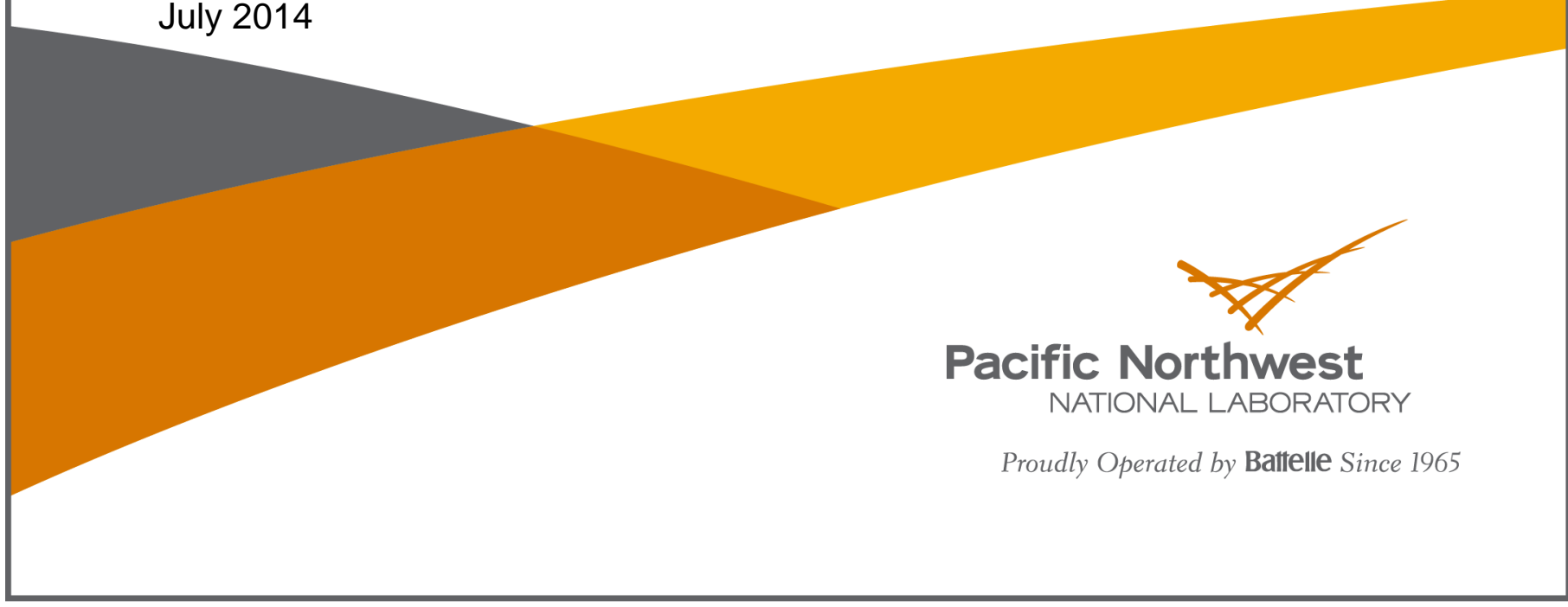




\title{
DISCLAIMER
}

This report was prepared as an account of work sponsored by an agency of the United States Government. Neither the United States Government nor any agency thereof, nor Battelle Memorial Institute, nor any of their employees, makes any warranty, express or implied, or assumes any legal liability or responsibility for the accuracy, completeness, or usefulness of any information, apparatus, product, or process disclosed, or represents that its use would not infringe privately owned rights. Reference herein to any specific commercial product, process, or service by trade name, trademark, manufacturer, or otherwise does not necessarily constitute or imply its endorsement, recommendation, or favoring by the United States Government or any agency thereof, or Battelle Memorial Institute. The views and opinions of authors expressed herein do not necessarily state or reflect those of the United States Government or any agency thereof.

\author{
PACIFIC NORTHWEST NATIONAL LABORATORY \\ operated by \\ BATTELLE \\ for the \\ UNITED STATES DEPARTMENT OF ENERGY \\ under Contract DE-AC05-76RL01830
}

Printed in the United States of America
Available to DOE and DOE contractors from the Office of Scientific and Technical Information,
P.O. Box 62, Oak Ridge, TN 37831-0062;
ph: (865) 576-8401
fax: (865) 576-5728
email: reports@adonis.osti.gov

\footnotetext{
Available to the public from the National Technical Information Service, U.S. Department of Commerce, 5285 Port Royal Rd., Springfield, VA 22161 ph: (800) 553-6847 fax: (703) 605-6900 email: orders@ntis.fedworld.gov online ordering: http://www.ntis.gov/ordering.htm
}

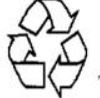

This document was printed on recycled paper. 


\section{Field-Derived Hydraulic Properties for Perched-Water Aquifer Wells 299-E33-350 and 299-E33-351, Hanford Site B- Complex Area}

DR Newcomer

July 2014

Prepared for

the U.S. Department of Energy

under Contract DE-AC05-76RL01830

Pacific Northwest National Laboratory

Richland, Washington 99352 


\section{Summary}

During February and March 2014, Pacific Northwest National Laboratory conducted hydraulic (slug) tests at 200-DV-1 Operable Unit wells 299-E33-350 (C8914) and 299-E33-351 (C8915) as part of BComplex Area perched-water characterization activities at the Hanford Site 200-East Area. During the construction/completion phase of each well, two overlapping depth intervals were tested within the unconfined perched-water aquifer contained in the silty-sand subunit of the Cold Creek Unit. The purpose of the slug-test characterization was to provide estimates of transmissivity and hydraulic conductivity for the perched-water aquifer at these selected well locations.

The slug-test results indicated a nonelastic, homogeneous-formation/exponential-decay (overdamped) pattern for slug tests conducted within the lower half of the perched Cold Creek silty-sand subunit. This slug-test response pattern was associated with low-permeability test conditions. For the respective $1.75-\mathrm{m}$ and $1.41-\mathrm{m}$ test/depth intervals within this lower half, type curve analyses indicate a best estimate average range for transmissivity of 1.26 to $1.92 \mathrm{~m}^{2} /$ day within this zone. This average range of transmissivity yields a best estimate average hydraulic-conductivity range of 0.72 to $1.36 \mathrm{~m} /$ day for the lower half of the perched-water aquifer at these two well locations.

For test/depth intervals that covered close to the full thickness of the perched-water aquifer, the slugtest results indicate a nonelastic, heterogeneous, composite-formation/exponential-decay (over-damped) type behavior at well 299-E33-350. This test behavior exhibits a higher permeability, inner (near-well) zone response during the initial recovery portion of the test that slowly transitions to a lower permeability response for the surrounding outer (far-well) zone formation. Type-curve analyses indicate a best estimate for transmissivity of $1.65 \mathrm{~m}^{2}$ /day within the $2.85-\mathrm{m}$ thick outer zone at this well location. This transmissivity yields a best estimate for hydraulic conductivity of $0.58 \mathrm{~m} /$ day for the full perched-water aquifer thickness at this well location.

For well 299-E33-351, the slug-test results indicate an elastic, homogeneous-formation/exponentialdecay (over-damped) pattern within an interval close to the full thickness of the perched-water aquifer. These slug-test responses exhibit a non-linear (concave-upward) pattern on a Bouwer and Rice semi-log plot. Type-curve analyses indicate a best estimate for transmissivity of $3.64 \mathrm{~m}^{2} /$ day within the $2.80-\mathrm{m}$ thick zone at this well location. This transmissivity yields a best estimate for hydraulic conductivity of $1.30 \mathrm{~m} /$ day for the full perched-water aquifer thickness at this well location.

Based on the hydraulic properties estimated for the four test/depth intervals, the principle of superposition method yields an inferred transmissivity range of 0.27 to $2.38 \mathrm{~m}^{2} /$ day for the upper half of the perched Cold Creek silty-sand subunit containing the perched water. This transmissivity range yields an inferred hydraulic-conductivity range of 0.18 to $2.27 \mathrm{~m} /$ day for the upper 1.05- to 1.44-m-thick half of the perched-water aquifer at these two well locations. All transmissivity and hydraulic-conductivity estimates for the perched-water aquifer assume uniform hydraulic properties within each of the wellscreen test/depth and inferred intervals. Estimates of transmissivity and hydraulic conductivity for all test/depth intervals within the perched silty-sand subunit are within the approximate range of transmissivity (i.e., 0.1 to $30 \mathrm{~m}^{2} /$ day) and hydraulic-conductivity (i.e., 0.1 to $10 \mathrm{~m} /$ day) values expected for silty-sand materials, assuming an equivalent test/depth interval thickness of 1.05 to $2.85 \mathrm{~m}$. 
The geometric average vertical hydraulic conductivity of intact core samples collected at the same boreholes used for the slug tests from 0.15-m intervals within the upper part of the Cold Creek silty-sand subunit perched-water aquifer ranges from 0.0022 to $0.135 \mathrm{~m} /$ day. This range yields a geometric mean of $0.017 \mathrm{~m} /$ day for vertical hydraulic conductivity within the upper part of the $\mathrm{CCU}_{\mathrm{z} \text { sand. }}$ Comparison of this mean with the geometric mean of $0.64 \mathrm{~m} /$ day for the inferred horizontal hydraulic conductivity indicates a vertical anisotropy ratio of approximately 0.026 for the upper half of the perched aquifer. This vertical anisotropy ratio estimated for the silty-sand subunit at the B-Complex wells is within the range (i.e., 0.001 to 1.0 ) expected for alluvial sediments.

The composite transmissivity of $3.64 \mathrm{~m}^{2} / \mathrm{d}$ for the perched-water aquifer at well 299-E33-351 is more than two times the perched-water aquifer transmissivity of $1.65 \mathrm{~m}^{2} / \mathrm{d}$ at well $299-\mathrm{E} 33-350$. This difference in transmissivity for the perched-water aquifer is consistent with the underlying unconfined aquifer uranium plume distribution at the B-Complex Area. Perched-water aquifer well 299-E33-351 is located within the plume area where the uranium concentrations $\geq 300 \mu \mathrm{g} / \mathrm{L}$, while well 299-E33-350 is located within the plume area where the concentrations $\geq 30 \mu \mathrm{g} / \mathrm{L}$ and $<300 \mu \mathrm{g} / \mathrm{L}$. 


\section{Acknowledgments}

Several staff contributed to the slug tests presented in this report. Bruce Williams of CH2M HILL Plateau Remediation Company provided identification of hydrogeologic units tested at the well sites. Jennifer Russell of Freestone Environmental Services, Inc. provided daily status reports and detailed well construction information that were essential for the slug-test analyses. Direction in the field was coordinated by Jim Mehrer of CH2M HILL Plateau Remediation Company and field support was provided by the drilling crew of Stillwater LLC.

In addition, Pacific Northwest National Laboratory staff contributed to the preparation of this report. Management support by Mike Truex is acknowledged. Frank Spane provided technical guidance and valuable peer review comments. Kirk Cantrell provided laboratory permeability test information for the intact core samples. Dave Lanigan provided graphics support. The editorial review provided by Susan Ennor is also acknowledged. 


\section{Acronyms and Abbreviations}

$\begin{array}{ll}\text { ASTM } & \text { American Society for Testing and Materials } \\ \mathrm{CCU} & \text { Cold Creek Unit } \\ \mathrm{CCU}_{\mathrm{g}} & \text { Cold Creek Unit gravel } \\ \mathrm{CCU}_{\mathrm{z}} & \text { Cold Creek Unit fine-grained subunit } \\ \mathrm{CCU}_{\mathrm{z} \text { lower }} & \text { Cold Creek Unit lower perching silt subunit } \\ \mathrm{CCU}_{\mathrm{z} \text { sand }} & \text { Cold Creek Unit silty-sand subunit } \\ \mathrm{CCU}_{\mathrm{z} \text { upper }} & \text { Cold Creek Unit upper silt subunit } \\ \text { DOE-RL } & \text { Department of Energy Richland Operations Office } \\ \text { bgs } & \text { below ground surface } \\ \text { I.D. } & \text { inside diameter } \\ \text { in. } & \text { inch(es) } \\ \text { KGS } & \text { Kansas Geological Survey } \\ \mathrm{kPa} & \text { kilopascal(s) } \\ \mathrm{m} & \text { meter(s) } \\ \mathrm{m}^{3} & \text { cubic meter(s) } \\ \text { O.D. } & \text { outside diameter } \\ \text { psig } & \text { pounds per square inch gauge } \\ \text { PST } & \text { Pacific Standard Time } \\ & \end{array}$




\section{Nomenclature}

b

$\mathrm{C}_{\mathrm{D}}$

g

$\mathrm{H}$

$\mathrm{H}_{\mathrm{o}}$

$\mathrm{H}_{\mathrm{p}}$

$\mathrm{K}$

$\mathrm{K}_{\mathrm{D}}$

$\mathrm{K}_{\mathrm{h}}$

$\mathrm{L}$

$\mathrm{L}_{\mathrm{e}}$

$\mathrm{R}_{\mathrm{e}}$

$\mathrm{r}_{\mathrm{c}}$

$\mathrm{r}_{\mathrm{w}}$

$\mathrm{S}_{\mathrm{s}}$

$\mathrm{T}$

$\mathrm{t}$

aquifer thickness; L

response-damping parameter; dimensionless

gravitational acceleration; $\mathrm{L} / \mathrm{T}^{2}$

deviation of hydraulic head in test well from static conditions; $\mathrm{L}$

theoretical slug-test stress level immediately after test initiation; $\mathrm{L}$

projected slug-test stress level immediately after test initiation; L

hydraulic conductivity; L/T

vertical anisotropy; dimensionless

hydraulic conductivity in the horizontal direction; $\mathrm{L} / \mathrm{T}$

saturated thickness of test interval within well-screen section; L

effective well water column length; L

effective test radius parameter; $\mathrm{L}$

stress well casing radius; $\mathrm{L}$

radius of stress well screen; $\mathrm{L}$

specific storage; $1 / \mathrm{L}$

transmissivity; $\mathrm{L}^{2} / \mathrm{T}$

elapsed time since start of the slug test; $\mathrm{T}$ 


\section{Contents}

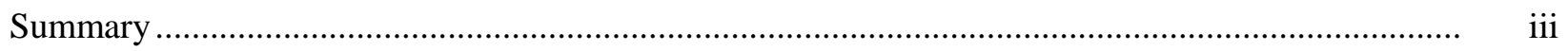

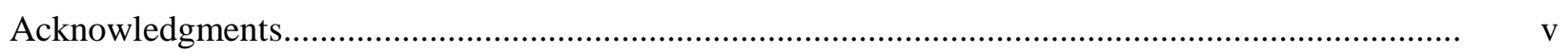

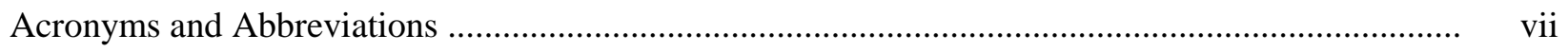

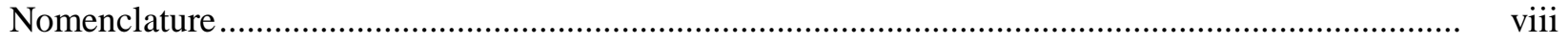

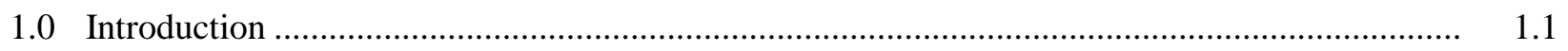

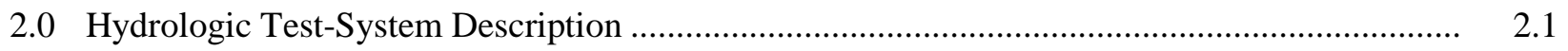

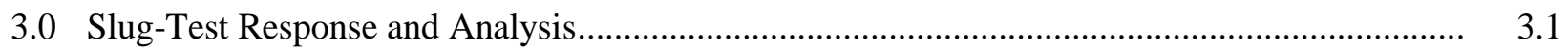

3.1 Over-Damped Slug-Test Diagnostic Evaluation ........................................................... 3.3

3.2 Over-Damped Type Curve Analysis Method................................................................ 3.4

3.3 Hydraulic Property Depth Profile Analysis...................................................................... 3.5

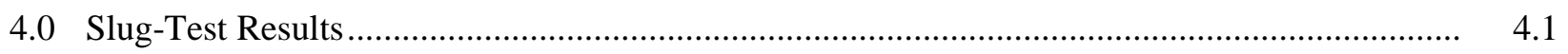

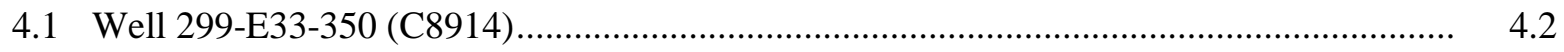

4.1.1 Zone 1 (Depth: 69.68 to $71.09 \mathrm{~m}$ ) ……............................................................... 4.2

4.1.2 Zone 2 (Depth: 68.24 to $71.09 \mathrm{~m})$.................................................................. 4.3

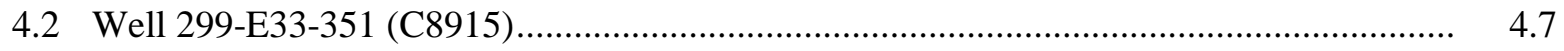

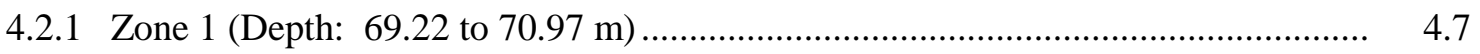

4.2.2 Zone 2 (Depth: 68.17 to $70.97 \mathrm{~m})$................................................................. 4.9

5.0 Hydraulic Property Depth Profile Comparison …................................................................ 5.1

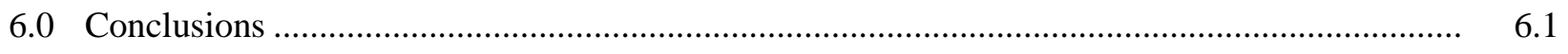

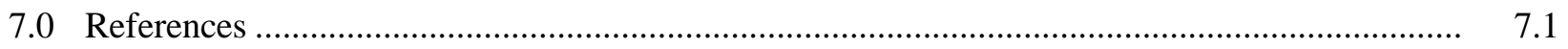




\section{Figures}

1.1 B-Complex Area Map Showing Locations of the Perched-Water Wells 299-E33-350

(C8914) and 299-E33-351 (C8915).

1.2 Generalized Conceptual Stratigraphic Model of the Perched-Water Zone near Wells 299-E33-344 and 299-E33-345

2.1 General Slug-Test Configuration within the Well-Screen Section during Construction of Wells 299-E33-350 and 299-E33-351

2.2 Photo of Slugging Rod used during Slug Testing of Wells 299-E33-350 and 299-E33-351 ........

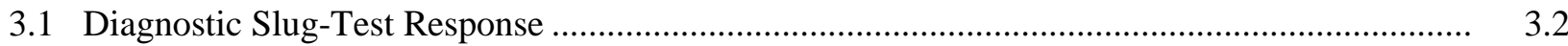

3.2 Over-Damped Slug-Test Response as a Function of Test-Interval Hydraulic Conductivity ........ 3.2

4.1 Selected Type-Curve Analysis Plot for Zone 1, Well 299-E33-350 (C8914) ........................... 4.3

4.2 Selected Bouwer and Rice Diagnostic Analysis Plot for Zone 2, Well 299-E33-350 (C8914)... 4.5

4.3 Selected Type-Curve Analysis Plots, Zone 2, Well 299-E33-350, for (a) the Artificially Created, High-Permeability Inner-Zone and (b) the Lower Permeability Outer-Zone Formation.

4.4 Selected Type-Curve Analysis Plot for Zone 1, Well 299-E33-351 (C8915) .......................... 4.9

4.5 Selected Bouwer and Rice Analysis Plot for Zone 2, Well 299-E33-351 (C8915)................... 4.10

4.6 Selected Type-Curve Analysis Plot for Zone 2, Well 299-E33-351 (C8915) ............................. 4.11

5.1 Hydraulic-Conductivity Depth Profile for Well 299-E33-350 (C8914) .................................... 5.2

5.2 Hydraulic-Conductivity Depth Profile for Well 299-E33-351 (C8915) .................................... 5.3

\section{Tables}

4.1 Slug-Test Characteristics for Selected Test/Depth Intervals at B-Complex Area Test Wells 299-E33-350 (C8914) and 299-E33-351 (C8915)

4.2 Slug-Test-Analysis Results for Wells 299-E33-350 (C8914) and 299-E33-351 (C8915)

5.1 Test-Zone Estimates of Transmissivity and Hydraulic Conductivity based on Average Type-Curve Slug-Test Analysis Results for the Silty-Sand Subunit of the Cold Creek FineGrained Unit 


\subsection{Introduction}

Perched water encountered in the deep vadose zone at the B-Complex Area contains elevated levels of radiological contamination and continues to be a persistent source of contamination to the underlying unconfined aquifer (DOE/RL-2013-52 [CHPRC 2013]). Hydrogeologic characterization information for the zone of perched water in this area is limited. Additional characterization data are needed to further develop the conceptual model of the site and to enhance the design of remediation strategies. Because of this need, a field hydraulic (slug) testing program was identified in DOE/RL-2013-52 as part of the BComplex Area, perched-water characterization activities for the 200-DV-1 Operable Unit, 200-East Area, at the Department of Energy's Hanford Site in Washington State (Figure 1.1).

Pacific Northwest National Laboratory conducted multiple slug-test characterizations during February and March 2014 for selected test/depth intervals within wells 299-E33-350 (C8914) and 299-E33-351 (C8915). Targeted test/depth intervals within the perched-water aquifer were characterized following temporary back-pulling of the drill casing, which exposed selected perched-aquifer sections within the final well screen and sand filter pack during final well completion/construction. The primary objective of the slug-test characterization was to provide in situ information pertaining to the vertical profile distribution of hydraulic properties (e.g., transmissivity [T] and hydraulic conductivity $[\mathrm{K}]$ ) within the unconfined perched-water aquifer at these selected well locations. Similar vertical profiling characterizations using slug testing has been successfully applied at other Hanford Site operable unit locations (Spane and Newcomer 2010a, b; Newcomer 2008).

The unconfined perched-water aquifer at the B-Complex Area lies within the Cold Creek fine-grained unit $\left(\mathrm{CCU}_{\mathrm{z}}\right)$ deep within the vadose zone above the regional unconfined aquifer (Truex et al. 2013). The $\mathrm{CCU}_{\mathrm{z}}$ is subdivided into three subunits: 1) a 1.8-m-thick lower perching silt subunit $\mathrm{CCU}_{\mathrm{z} \text { lower }}$; 2) a 4.9m-thick silty-sand subunit $\mathrm{CCU}_{\mathrm{z} \text { sand }}$ with higher sand content; and 3) a 1.8-m-thick upper silt subunit $\mathrm{CCU}_{\mathrm{z} \text { upper }}$ at the top of the $\mathrm{CCU}_{\mathrm{z}}$ (Figure 1.2, Truex et al. 2013; Williams et al. 2012). Specifically, the perched-water aquifer lies within the $\mathrm{CCU}_{\mathrm{z} \text { sand }}$ between the perched water table and the top of the underlying perching $\mathrm{CCU}_{\mathrm{z} \text { lower, }}$ yet below the $\mathrm{CCU}_{\mathrm{z} \text { upper }}$ layer. The perching $\mathrm{CCU}_{\mathrm{z} \text { lower }}$ subunit acts as a natural barrier to groundwater flow that slows contaminant migration between the perched-water aquifer and the underlying unconfined aquifer. 


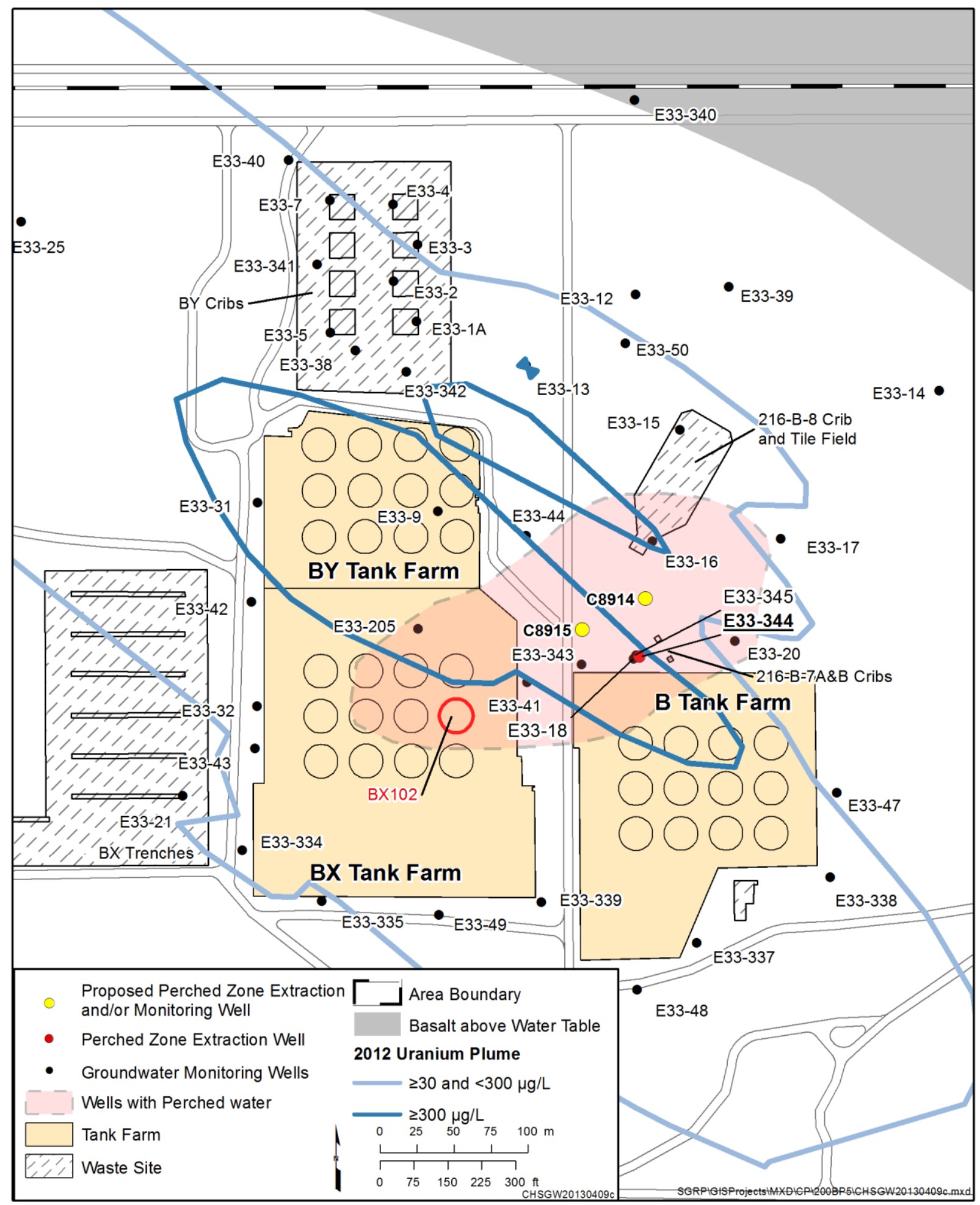

Figure 1.1. B-Complex Area Map Showing Locations of the Perched-Water Wells 299-E33-350 (C8914) and 299-E33-351 (C8915). (Source: Bruce Williams, CH2M HILL Plateau Remediation Company) 


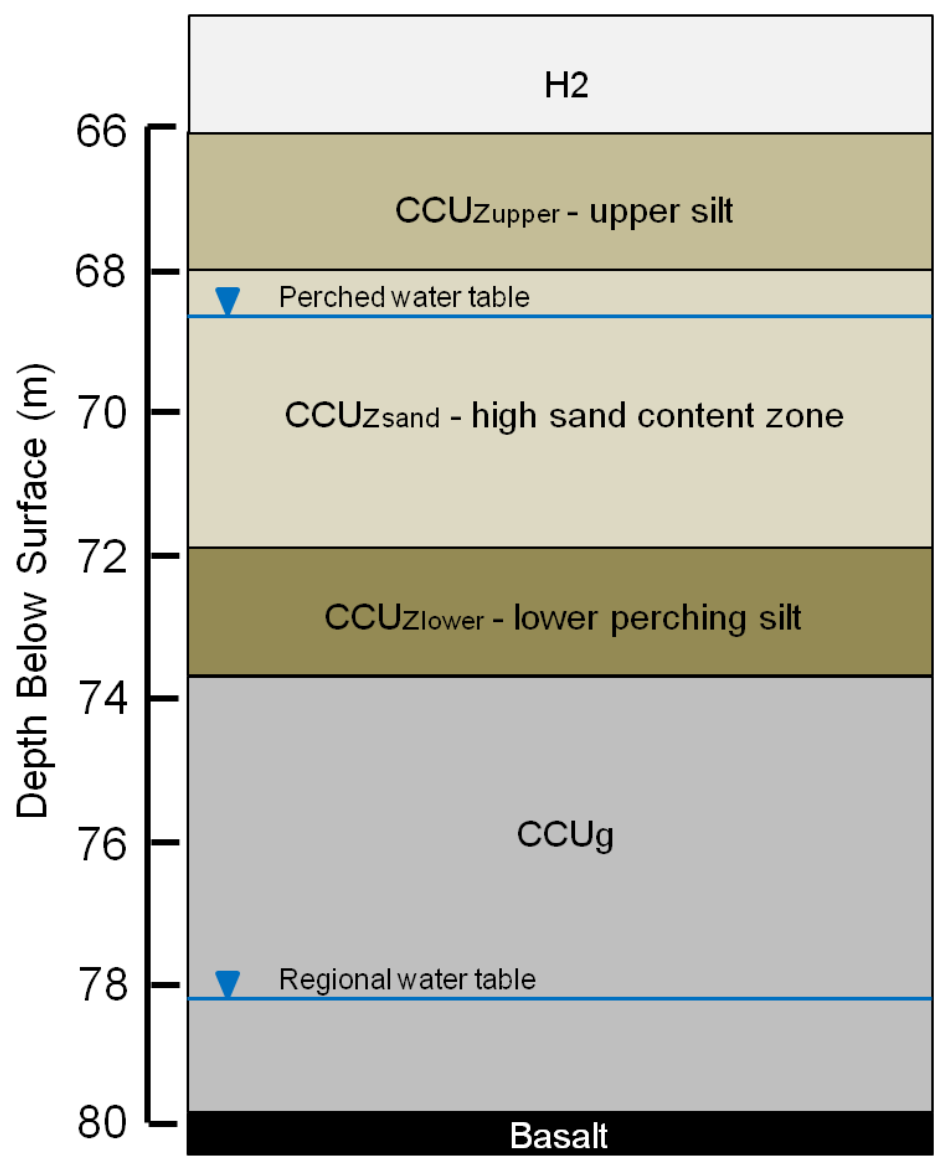

Figure 1.2. Generalized Conceptual Stratigraphic Model of the Perched-Water Zone near Wells 299-E33-344 and 299-E33-345 (after Truex et al. 2013). The full thickness of the Hanford formation $\mathrm{H} 2$ unit is not depicted. The Cold Creek Unit silt $\left(\mathrm{CCU}_{\mathrm{z}}\right)$ in the area with perched water is composed of a lower perching silt $\left(\mathrm{CCU}_{\mathrm{z} \text { lower }}\right)$, a high sand content zone $\left(\mathrm{CCU}_{\mathrm{z} \text { sand }}\right)$, and an upper silt zone $\left(\mathrm{CCU}_{\mathrm{z} \text { upper }}\right)$. The Cold Creek Unit gravel $\left(\mathrm{CCU}_{\mathrm{g}}\right)$ contains the regional groundwater and is underlain by basalt. 


\subsection{Hydrologic Test-System Description}

Slug-test characterization was implemented during well-completion activities after drilling had reached total depth to the bottom of the perched-water aquifer. To prepare the test zone for slug-test characterization, the permanent well-screen/casing assembly was lowered to the bottom of the borehole, and a silica sand filter pack was placed in the annulus while the drill casing was retracted, exposing the well screen to approximately the lower half of the $\sim 3$-m-thick perched-water aquifer. The test/depth interval was then surged to develop the well-screen section exposed to the unit prior to formal slug testing activities. Surging involves the raising and lowering of a surge block or bailer multiple times inside the well to force water into and out of the well screen (Driscoll 1986). The surging action removes fine particles from the formation and stabilizes the sand filter pack surrounding the well-screen test section. Following slug testing of this test/depth interval, well completion continued with emplacement of additional sand filter pack and retraction of the drill casing, exposing the well screen to nearly the entire perched-water aquifer within $\mathrm{CCU}_{\mathrm{z} \text { sand. }}$. This exposed section was then surged again to develop the upper half of the well-screen section in preparation for slug testing of this longer test/depth interval.

Multiple-stress-level slug testing is the standard approach for determining whether the associated slug-test responses exhibit a variable or stress-level dependence, as noted by Butler (1998). Tests exhibiting either variable or stress-level dependence can provide valuable information pertaining to the presence of dynamic well skin test-response conditions occurring within the test section. It was impractical, however, to conduct multiple slug tests using varying stress levels at the B-Complex Area boreholes because of the expected long slug-test response times (i.e., for low-permeability conditions), and the limited thickness of the saturated perched aquifer. Because of these limitations, only one slug injection test and one slug withdrawal test (of equal stress level) were attempted for each separate testinterval section. Because of the limited number of the slug tests conducted, no assessment can be provided with regard to the presence of dynamic well skin conditions for the B-Complex Area boreholes.

Figure 2.1 shows the general test-system configuration used for the slug tests conducted during the construction of wells 299-E33-350 and 299-E33-351. The boreholes were partially completed with the final 0.152-m O.D. (6-in. O.D.), 40-slot well screen, and 20-40 mesh silica sand filter pack, and the temporary drill casings were back-pulled during well construction, exposing the well screen to the perched-aquifer formation. Slug tests were conducted with a single 1.2-m-long, 0.114-m O.D. (4.5-in. O.D.) slugging rod for all test/depth intervals (Figure 2.2). The test-system configuration includes a downhole pressure transducer/cable, a slugging rod lowered by a drill rig (Figure 2.2), and a surface data logger system. A Druck, Inc. strain-gauge, 0 - to $35-\mathrm{kPa}(0-$ to 5 -psig) or 0 - to $69-\mathrm{kPa}(0-$ to $10-\mathrm{psig})$ pressure transducer was installed below the fluid-column surface within the well-screen section to monitor downhole test-interval responses before, during, and after slug testing. Pressure-transducer measurements were recorded with a Campbell Scientific, Inc. model CR-10X ${ }^{\mathrm{TM}}$ data logger. 


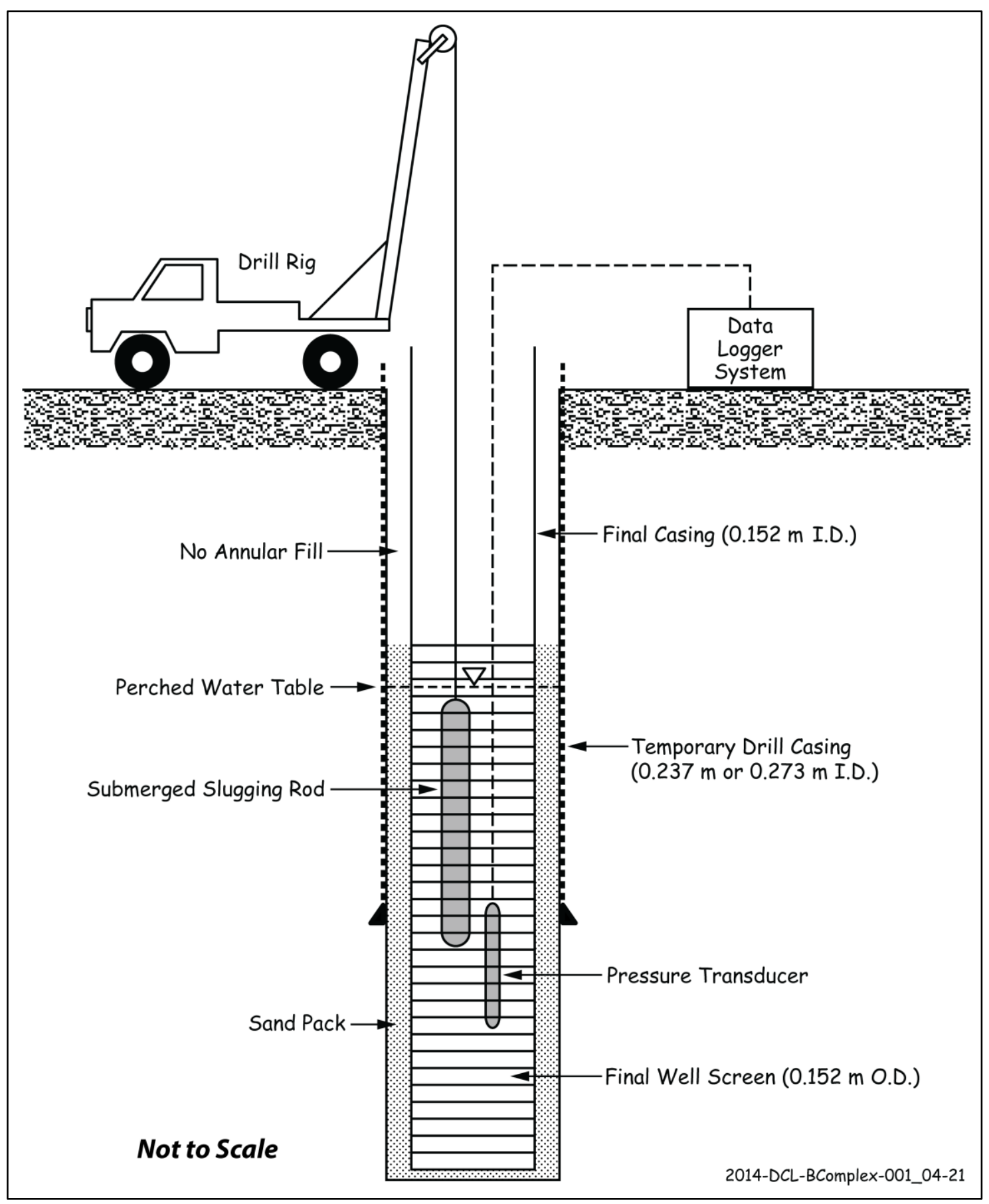

Figure 2.1. General Slug-Test Configuration within the Well-Screen Section during Construction of Wells 299-E33-350 and 299-E33-351 


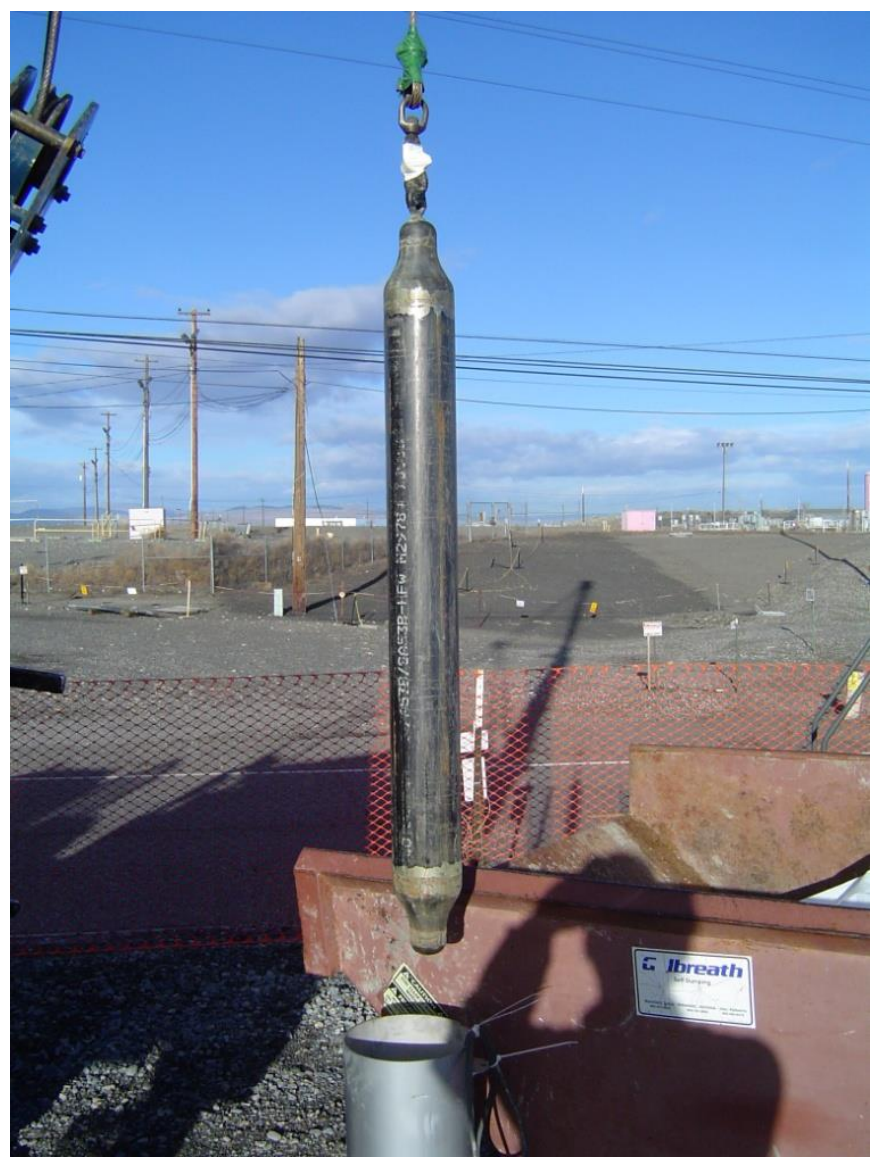

Figure 2.2. Photo of Slugging Rod Used during Slug Testing of Wells 299-E33-350 and 299-E33-351 


\subsection{Slug-Test Response and Analysis}

The majority of this section is taken from previous slug-test response and analysis discussions presented by Spane and Newcomer (2008). As discussed by Butler (1998) and Spane et al. (2003), water levels within a test well can respond in one of three ways to the instantaneously applied stress of a slug test (Figure 3.1). These response model patterns are 1) an over-damped response in which the water levels recover in an exponentially decreasing recovery pattern; 2) an under-damped response in which the slug-test response oscillates above and below the initial static, with decreasing peak amplitudes with time; and 3) a critically damped response in which the slug-test behavior exhibits characteristics that are transitional to the over- and under-damped response patterns. Factors that control the type of slug-test response model that are exhibited within a well include a number of aquifer properties (e.g., hydraulic conductivity) and well-dimension characteristics (e.g., well-screen length, well-casing radius, well radius, aquifer thickness, fluid-column length, etc.) and can be expressed by the response-damping parameter, $C_{D}$, which Butler (1998) reports for unconfined aquifer tests as

$$
C_{D}=\sqrt{\frac{g}{L_{e}}} * \frac{r_{c}^{2} \ln \left[R_{e} / r_{w}\right]}{2 K L}
$$

where

$$
\begin{aligned}
\mathrm{g} & =\text { acceleration due to gravity } \\
\mathrm{L}_{\mathrm{e}} & =\text { effective well water column length } \\
\mathrm{r}_{\mathrm{c}} & =\text { well-casing radius (i.e., radius of well water column that is active during testing) } \\
\mathrm{R}_{\mathrm{e}} & =\text { effective test radius parameter; as defined by Bouwer and Rice (1976) } \\
\mathrm{r}_{\mathrm{w}} & =\text { well radius } \\
\mathrm{K} & =\text { hydraulic conductivity of test interval } \\
\mathrm{L} & =\text { well-screen length. }
\end{aligned}
$$

An over-damped test response generally occurs within stress wells that are monitoring test formations of low to moderately high hydraulic conductivity, and is indicative of test conditions where frictional forces (i.e., resistance of groundwater flow from the test interval to the well) are predominant over testsystem inertial forces. Figure 3.2 shows predicted slug-test recovery as a function of hydraulic conductivity (K range: 0.1 to $10 \mathrm{~m} /$ day; $1.0-\mathrm{m}$ test interval) for test intervals exhibiting over-damped response characteristics and for general B-Complex Area test well/interval conditions. The test predictions shown in the figure are based on responses occurring within a test-system casing with a $0.152 \mathrm{~m}$ I.D. The test-response data were calculated using the Kansas Geological Survey (KGS) analytical model described by Liu and Butler (1995) for the given test parameters shown in the figure. As indicated in the figure, test intervals having hydraulic-conductivity values of approximately $10 \mathrm{~m} /$ day or less should be readily resolved for tests exhibiting over-damped slug-test behavior. For over-damped slug tests, two different methods can be used for the slug-test analysis: 1) the semi-empirical, straight-line analysis method described by Bouwer and Rice (1976) and Bouwer (1989) and 2) the type curvematching method for unconfined aquifers presented by Butler (1998). For over-damped slug tests, hydraulic-conductivity estimates obtained with the Bouwer and Rice (1976) analytical method are used for comparison purposes. These estimates are generally less reliable than corresponding estimates obtained with the type curve-matching method (Hyder and Butler 1995; Butler 1998). Detailed descriptions of over-damped, slug-test-analysis methods have been reported by Spane and Newcomer (2004, 2008). 


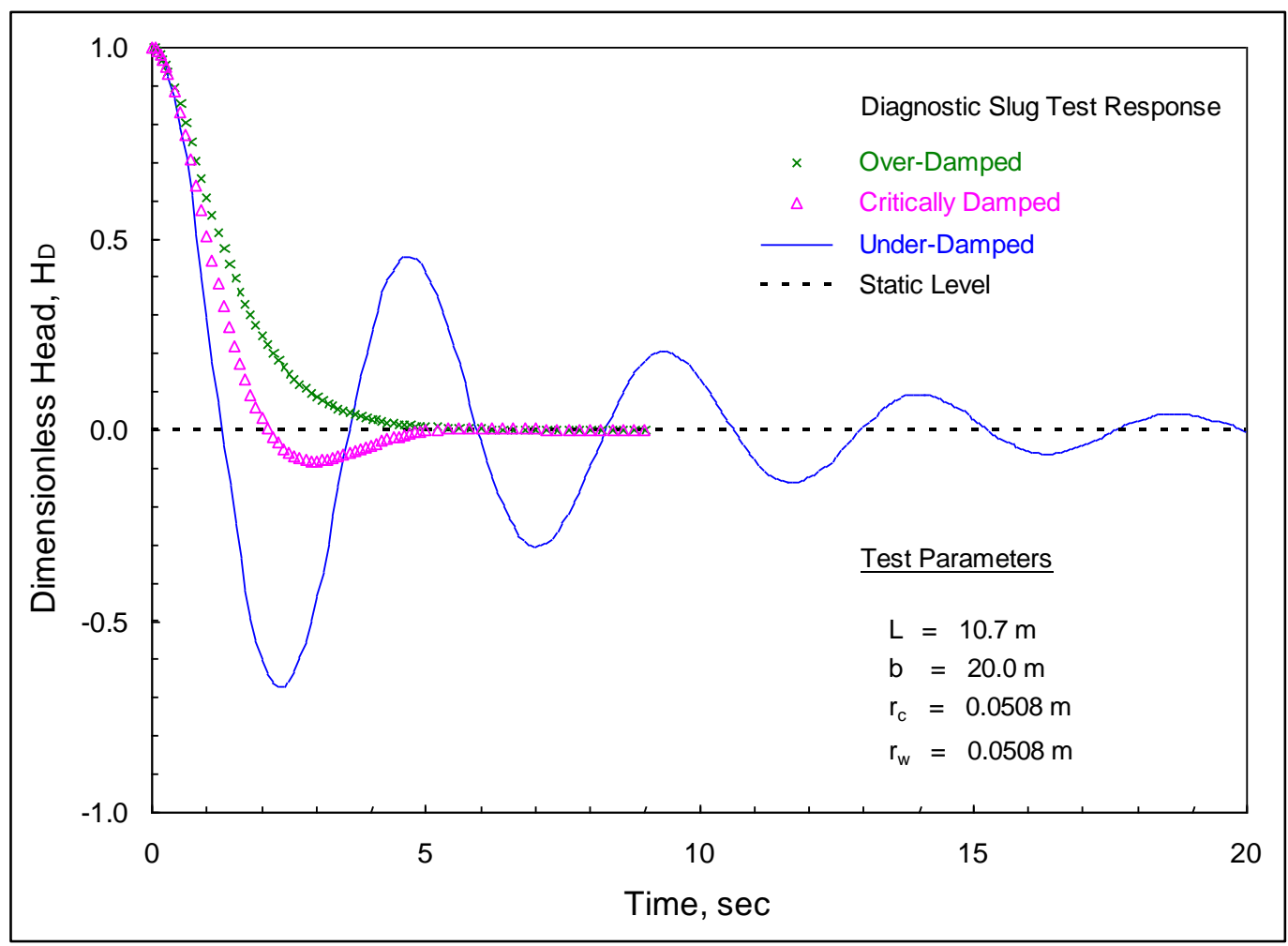

Figure 3.1. Diagnostic Slug-Test Response (taken from Spane and Newcomer 2008)

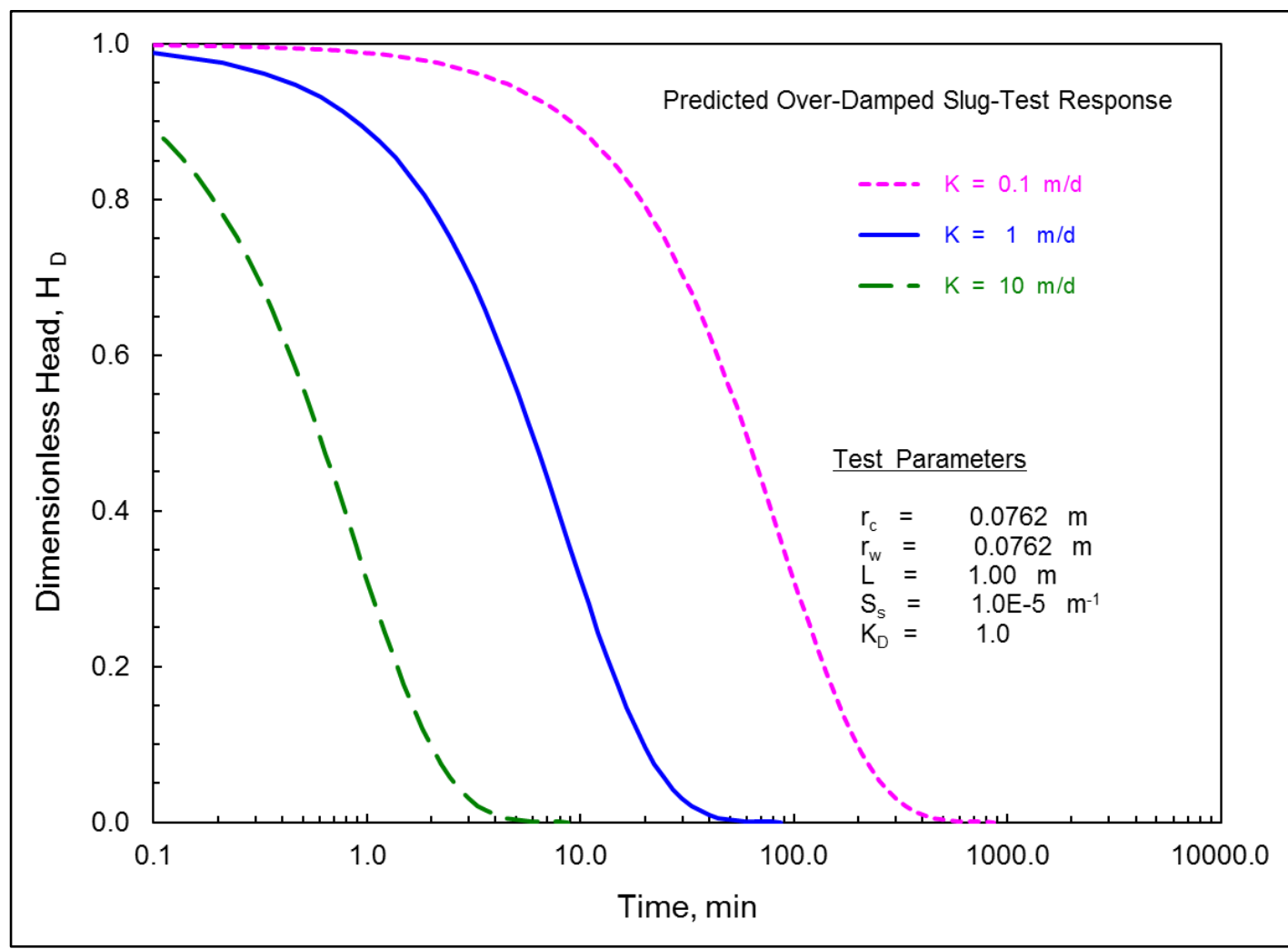

Figure 3.2. Over-Damped Slug-Test Response as a Function of Test-Interval Hydraulic Conductivity 
Under-damped test-response patterns are exhibited within stress wells where inertial forces are predominant over formational frictional forces. This commonly occurs in wells with extremely long fluid columns (i.e., a large water mass within the well column) and/or that penetrate high-permeability aquifers (e.g., the Hanford formation). Tests exhibiting under-damped behavior should be conducted with very small stress-level applications. No B-Complex Area well-test intervals displayed formational testresponse characteristics that were under-damped.

As mentioned previously, critically damped test responses are indicated by stress well water-level responses that are transitional to the over- and under-damped test conditions, as shown in Figure 3.1. They typically occur in wells that monitor test formations exhibiting intermediate to high hydraulic conductivity. As noted by Butler (1998), distinguishing between slug-test responses that are over-damped and critically damped may be difficult in some cases (i.e., due to test signal noise) when examined on arithmetic plots. Proper model identification may be enhanced when semi-log plots are used (i.e., $\log$ head versus time [e.g., Bouwer and Rice plot]). Critically damped slug tests exhibit a diagnostic concavedownward pattern when plotted in this semi-log plot format. This is in contrast to over-damped response behavior, which displays either a linear or concave-upward (elastic) pattern. Critically damped slug-test responses are influenced by processes (e.g., inertial) that are not accounted for in the previously discussed slug-test analytical methods (i.e., for over-damped tests). Because of this, slug tests exhibiting these response characteristics cannot be analyzed quantitatively with the Bouwer and Rice or standard type curve methods. High-K analysis methods that can be employed for analyzing unconfined aquifer tests exhibiting response behavior that is either critically damped or under-damped include those described by Springer and Gelhar (1991), Butler (1998), McElwee and Zenner (1998), McElwee (2001), Butler and Garnett (2000), and Zurbuchen et al. (2002). Because of the ease provided by a spreadsheet-based approach, the test-analysis method presented by Butler and Garnett (2000) is preferred for analyzing tests exhibiting critically damped behavior. Detailed discussions of this analytical procedure and method have been reported by Spane and Newcomer $(2004,2008)$. No B-Complex Area well-test intervals displayed formational test-response characteristics that were critically damped.

\subsection{Over-Damped Slug-Test Diagnostic Evaluation}

Diagnostic evaluation of the over-damped slug-test response data involves plotting the normalized head data (i.e., $\mathrm{H} / \mathrm{H}_{\mathrm{o}}$ ) versus time for determining whether the slug-test responses are linear (i.e., nonelastic) or non-linear (i.e., elastic) on a semi-log plot. The presence of elastic aquifer storage (i.e., specific storage, $\mathrm{S}_{\mathrm{s}}$ ) will display curvilinear test responses (concave-upward) that deviate from the predicted linear, nonelastic formation type of response. When this curvilinear slug-test response is evident on a semi-log plot, Butler $(1996,1998)$ recommends analyzing the normalized head segment between 0.3 and 0.2 (i.e., linear regression slope) when using the Bouwer and Rice (1976) method.

Diagnostic evaluation of over-damped response data also employs the use of slug-test derivative type curves for defining radial heterogeneity surrounding the test well (Spane and Newcomer 2008). The effects of radial variations of hydraulic properties surrounding the test well have been investigated by Moench and Hsieh (1985) in studies examining slug tests in the presence of a finite-thickness skin condition. A finite-thickness skin is a radial boundary condition surrounding the well where the inner (i.e., near-well) zone has different hydraulic properties than that of the outer (i.e., far-well) zone. For data analyzed for one of the well-test/depth intervals at the B-Complex Area, $\mathrm{K}$ of the inner zone was greater than that of the outer zone, indicating a negative skin effect. As discussed by Spane (1993), slug tests 
exhibiting linear-response characteristics for radial heterogeneous formation tests can be analyzed with the homogeneous-formation analysis approaches. The DERIV code was used to calculate the slug-test pressure derivatives for determining radial heterogeneity surrounding the well-test/depth interval (Spane and Wurstner 1993).

\subsection{Over-Damped Type Curve Analysis Method}

The type curve analysis method is very useful for analyzing over-damped slug-test responses in unconfined aquifers (including unconfined perched-water aquifers) because the method can analyze all or any part of the slug-test response data set. This method does not have any of the Bouwer and Rice (1976) inherent analytical weaknesses, which are described in more detail by Spane and Newcomer (2008). The slug-test type curve analyses of the perched-water aquifer slug tests were standardized by setting initial analysis parameters, as follows:

- a vertical anisotropy of 1.0

- a specific storage, $\mathrm{S}_{\mathrm{s}}$, of $1 \mathrm{E}-5 \mathrm{~m}^{-1}$

- an exposed well-screen section (i.e., exposed to the perched-water aquifer below or across the perched water table) that was equivalent to the test/depth interval.

A vertical anisotropy of 1.0 was assumed for all slug-test response type curve-matching analyses. Single-well slug-test responses are relatively insensitive to vertical anisotropy. Except for highly anisotropic systems, Butler (1998) indicates that a vertical anisotropy range of 0.3 to 1.0 introduces an error not exceeding $20 \%$ in the hydraulic-conductivity estimate for unconfined aquifers. A vertical anisotropy of 0.1 versus 1.0 applied to the unconfined perched-water aquifer slug-test type curve analyses indicated an increase of only 30 to $40 \%$ in the hydraulic-conductivity estimates for the B-Complex welltest intervals.

An $\mathrm{S}_{\mathrm{s}}$ value of $1 \mathrm{E}-5 \mathrm{~m}^{-1}$, a physically plausible value for unconfined (i.e., perched-water) aquifers (Butler 1998; Batu 1998), was used for all initial analysis runs. After initial type curve matches were made with the slug-test response data and test-data derivative through adjustments of transmissivity, T, additional adjustments of $S_{s}$ were then made to improve the overall match of the slug-test response. For three of the four slug-test/depth intervals analyzed, modifications of the $S_{s}$ estimate was made by increasing the $S_{s}$ input values to improve the final type curve analysis matches. Because other factors (e.g., dynamic skin effects) influence the shape of the slug-test type curve, the $\mathrm{S}_{\mathrm{s}}$ estimates obtained from the slug-test type curve analyses for the B-Complex wells are considered to be qualitative and should not be used for quantitative applications.

The exposed section of the well screen below or across the perched water table instead of the sand filter-pack interval was used to represent the test interval for the slug-test analysis. This assumes that the perched formation materials within the exposed well-screen section have a higher permeability than the sand filter-pack permeability. Because of this assumption, transmission of the slug-test response will propagate faster laterally from the well-screen test interval to the surrounding test formation than vertically within/through the sand filter pack. Butler (1996) showed that the well-screen length (i.e., the exposed portion of the well screen) is a better estimate for the test/depth interval than the length of the filter-pack material for conditions commonly found in the field. 
The slug-test response data were analyzed by matching the type curves generated using the KGS program model described by Liu and Butler (1995). The KGS program provides a semi-analytical solution to slug tests for isotropic or anisotropic conditions and a fully or partially penetrating well under confined or unconfined aquifer conditions. The KGS solution is not strictly valid for the boundary condition where the perched water table occurs within the well-screen test section because the effective well-screen test length changes during the slug test (Butler 1998). However, the initial displacement $\left(\mathrm{H}_{\mathrm{o}}\right)$ exerted for each B-Complex perched-water slug test was small (i.e., <25\% as recommended by Butler [1998]) relative to the effective well-screen test length at static conditions. Also, a comparison of slugtest type curves generated from converted unconfined pumping-test type curves, which accounts for the water table boundary effect, indicates very little difference in predicted slug-test responses when compared to type curves generated by the KGS model (Spane 1996). For these reasons, and the fact that the KGS program calculates type curve slug-test responses directly and can be applied more readily for analyzing slug-test data than other programs, it was used as the type curve analysis program for the perched-water aquifer slug tests.

\subsection{Hydraulic Property Depth Profile Analysis}

As noted by Spane (2007), for slug-test interval characterizations conducted within zones that overlap, the vertical profile of hydraulic properties estimated from these slug tests can be used to infer hydraulic properties using the principle of superposition (Reilly et al. 1987). The principle of superposition is the simple concept that solutions from individual parts are additive in solving a composite problem. In hydrologic testing applications, hydraulic properties (i.e., transmissivity) estimated from individual, overlapping hydrologic test zones can be summed to infer transmissivity. Vertical profiling characterizations using slug-test results have been successfully applied at other Hanford Site operable unit locations (Spane and Newcomer 2010a, b; Newcomer 2008).

Strictly speaking, the superposition principle is only valid for linear-response aquifer systems (e.g., confined aquifers). However, Reilly et al. (1987) state that it is also appropriate for unconfined aquifers, which includes unconfined perched-water aquifers (i.e., non-linear-response systems), if test stress levels

are kept within $10 \%$ of the unconfined aquifer's thickness. This was the case for the slug tests conducted within the perched-water aquifer at the B-Complex Area boreholes. 


\subsection{Slug-Test Results}

The following discussion presents pertinent information describing slug testing activities and analysis results for the test/depth zones that were hydrologically characterized at the B-Complex Area boreholes as they were completed during well construction.

Table 4.1 presents slug-test information for the respective test/depth intervals, while Table 4.2 summarizes the results from slug-test analysis. The results in Table 4.2 represent the first known in situ field-scale, hydraulic property estimates for the Cold Creek fine-grained unit at the Hanford Site and represent horizontal hydraulic properties. Borehole logs for the tested wells are presented in the borehole summary report for B-Complex Area Wells 299-E33-350 (C8914) and 299-E33-351 (C8915) (CHPRC 2014), which can be referred to for a geologic description of the respective well-test zone/depth intervals.

Table 4.1. Slug-Test Characteristics for Selected Test/Depth Intervals at B-Complex Area Test Wells 299-E33-350 (C8914) and 299-E33-351 (C8915)

\begin{tabular}{|c|c|c|c|c|c|c|c|}
\hline \multirow{2}{*}{$\begin{array}{l}\text { Test Well } \\
\text { Number } \\
\text { (Borehole } \\
\text { I.D.) }\end{array}$} & \multirow[b]{2}{*}{$\begin{array}{l}\text { Test } \\
\text { Zone }\end{array}$} & \multicolumn{4}{|c|}{ Test Parameters } & \multirow[b]{2}{*}{$\begin{array}{c}\text { Diagnostic Slug-Test } \\
\text { Response Model }\end{array}$} & \multirow[b]{2}{*}{$\begin{array}{l}\text { Hydrogeologic } \\
\text { Unit Tested }\end{array}$} \\
\hline & & Test Date & $\begin{array}{c}\text { Number } \\
\text { of Slug } \\
\text { Tests }\end{array}$ & $\begin{array}{l}\text { Depth to } \\
\text { Water } \\
(\mathrm{m} \mathrm{bgs})^{(\mathrm{a})}\end{array}$ & $\begin{array}{c}\text { Depth/Test } \\
\text { Interval } \\
\text { (m bgs) }\end{array}$ & & \\
\hline \multirow{2}{*}{$\begin{array}{l}\text { 299-E33-350 } \\
\quad(\mathrm{C} 8914)\end{array}$} & Zone 1 & $3 / 5 / 14$ & 2 & 68.21 & $69.68-71.09$ & $\begin{array}{l}\text { Nonelastic, } \\
\text { Homogeneous } \\
\text { Formation/ } \\
\text { Exponential-Decay } \\
\text { (over-damped) }\end{array}$ & $\begin{array}{l}\text { Cold Creek fine- } \\
\text { grained unit } \\
\left(\mathrm{CCU}_{\mathrm{z} \text { sand }}\right)\end{array}$ \\
\hline & Zone 2 & $\begin{array}{c}3 / 5 / 14 \text { to } \\
3 / 6 / 14\end{array}$ & $2^{(\mathrm{b})}$ & 68.24 & $68.24-71.09$ & $\begin{array}{l}\text { Nonelastic, } \\
\text { Heterogeneous, } \\
\text { Composite- } \\
\text { Formation/ } \\
\text { Exponential-Decay } \\
\text { (over-damped) }\end{array}$ & $\begin{array}{l}\text { Cold Creek fine- } \\
\text { grained unit } \\
\left(\mathrm{CCU}_{\mathrm{z} \text { sand }}\right)\end{array}$ \\
\hline \multirow{2}{*}{$\begin{array}{l}\text { 299-E33-351 } \\
\quad(\mathrm{C} 8915)\end{array}$} & Zone 1 & $2 / 26 / 14$ & 2 & 68.24 & $69.22-70.97$ & $\begin{array}{l}\text { Nonelastic, } \\
\text { Homogeneous } \\
\text { Formation/ } \\
\text { Exponential-Decay } \\
\text { (over-damped) }\end{array}$ & $\begin{array}{l}\text { Cold Creek fine- } \\
\text { grained unit } \\
\left(\mathrm{CCU}_{\mathrm{z} \text { sand }}\right)\end{array}$ \\
\hline & Zone 2 & $3 / 5 / 14$ & 2 & 68.17 & $68.17-70.97$ & $\begin{array}{l}\text { Elastic, } \\
\text { Homogeneous } \\
\text { Formation/ } \\
\text { Exponential-Decay } \\
\text { (over-damped) }\end{array}$ & $\begin{array}{l}\text { Cold Creek fine- } \\
\text { grained unit } \\
\left(\mathrm{CCU}_{\mathrm{z} \text { sand }}\right)\end{array}$ \\
\hline \multicolumn{8}{|c|}{ (a) bgs = below ground surface } \\
\hline $\begin{array}{l}\text { (b) Slug inj } \\
\text { logger a }\end{array}$ & $\begin{array}{l}\text { tion tes } \\
\text { pressu }\end{array}$ & $\begin{array}{l}\text { not analyze } \\
\text { transduce }\end{array}$ & de to da & at 7.6 & $13.2 \mathrm{~min}$ ass & ated with wiring discol & ction between data \\
\hline
\end{tabular}


Table 4.2. Slug-Test-Analysis Results for Wells 299-E33-350 (C8914) and 299-E33-351 (C8915)

\begin{tabular}{|c|c|c|c|c|}
\hline \multirow{2}{*}{$\begin{array}{l}\text { Test Well } \\
\text { Number } \\
\text { (Borehole } \\
\text { I.D.) }\end{array}$} & \multirow[b]{2}{*}{ Test Zone } & \multicolumn{2}{|c|}{ Type-Curve Analysis Method } & \multirow{2}{*}{$\begin{array}{c}\text { Bouwer and Rice Method } \\
\begin{array}{c}\text { Hydraulic Conductivity, } \mathrm{K}_{\mathrm{h}} \text { (a) } \\
\text { (m/day) }\end{array}\end{array}$} \\
\hline & & $\begin{array}{c}\text { Hydraulic } \\
\text { Conductivity, } \mathrm{K}_{\mathrm{h},}{ }^{\text {(a) }} \\
(\mathrm{m} / \text { day })\end{array}$ & $\begin{array}{c}\text { Specific Storage, } \\
\mathrm{S}_{\mathrm{s}}\left(\mathrm{m}^{-1}\right)\end{array}$ & \\
\hline \multirow{3}{*}{$\begin{array}{l}\text { 299-E33-350 } \\
\quad(C 8914)\end{array}$} & Zone 1 & $1.20-1.51(1.36)$ & $2.0 \mathrm{E}-3-3.0 \mathrm{E}-3$ & $1.12-1.43(1.28)$ \\
\hline & $\begin{array}{c}\text { Zone } 2 \\
\text { (Inner Zone) } \\
\end{array}$ & 2.88 & $1.0 \mathrm{E}-5$ & 2.55 \\
\hline & $\begin{array}{c}\text { Zone } 2 \\
\text { (Outer Zone) }\end{array}$ & 0.58 & $1.0 \mathrm{E}-5$ & 0.40 \\
\hline \multirow{2}{*}{$\begin{array}{l}\text { 299-E33-351 } \\
\quad(\mathrm{C} 8915)\end{array}$} & Zone 1 & $0.62-0.82(0.72)$ & $1.0 \mathrm{E}-5-9.0 \mathrm{E}-4$ & $0.57-0.67(0.62)$ \\
\hline & Zone 2 & $1.15-1.44(1.30)$ & $8.0 \mathrm{E}-4-1.0 \mathrm{E}-3$ & $1.15-1.47(1.31)$ \\
\hline
\end{tabular}

Note: Number in parentheses is the average value for all tests.

(a) Assumed to be uniform within the well-screen test section.

\subsection{Well 299-E33-350 (C8914)}

The drilling of B-Complex well 299-E33-350 reached a total depth of $71.63 \mathrm{~m}$ bgs. The lower silt subunit $\left(\mathrm{CCU}_{\mathrm{z} \text { lower }}\right)$ of the fine-grained $\mathrm{CCU}\left(\mathrm{CCU}_{\mathrm{z}}\right)$ was encountered at a depth of $71.45 \mathrm{~m}$ bgs, which represents the bottom boundary of the perched-water aquifer at this location. The $\sim 3.2$-m-thick perchedwater aquifer occurs within the silty-sand subunit $\mathrm{CCU}_{\mathrm{z} \text { sand }}$, which overlies the $\mathrm{CCU}_{\mathrm{z} \text { lower }}$. Two test-depth intervals were tested at this borehole location during well completion: Zone $1=69.68$ to $71.09 \mathrm{~m}$ bgs and Zone $2=68.24$ to $71.09 \mathrm{~m}$ bgs. The static water-level depth during hydrologic testing ranged between 68.21 and $68.24 \mathrm{~m}$ bgs.

\subsubsection{Zone 1 (Depth: 69.68 to $71.09 \mathrm{~m}$ )}

The 40-slot, 6-in. stainless steel well-screen assembly was lowered to the bottom of the borehole at a depth of $71.20 \mathrm{~m}$ bgs. The borehole was back-filled with 20-40 mesh silica sand filter pack to a depth of $68.64 \mathrm{~m}$ bgs and the 0.2985-m O.D. (11-3/4-in. O.D.) drill casing was back-pulled $1.95 \mathrm{~m}$ (i.e., from 71.63 to $69.68 \mathrm{~m} \mathrm{bgs}$ ), exposing the lower $1.41 \mathrm{~m}$ of the 3.05 -m-long well screen to the perched-water aquifer. This produced a test/depth interval for Zone 1 of 69.68 to $71.09 \mathrm{~m}$ bgs within the lower part of the siltysand subunit $\mathrm{CCU}_{\mathrm{z} \text { sand. }}$ Surging was performed to develop the exposed section of the well screen and perched water table conditions were allowed to stabilize before initiating the slug tests.

Two slug tests (one injection and one withdrawal test) were conducted at 0759 hours and 1007 hours (Pacific Standard Time [PST]), respectively, on March 5, 2014. The slugging rod was fully submerged in the water column, with a fully submerged estimated volume of $0.0109 \mathrm{~m}^{3}$. This slug-rod volume imparted a theoretical applied stress level $\left(\mathrm{H}_{\mathrm{o}}\right)$ of $0.185 \mathrm{~m}$ within the $0.273-\mathrm{m} \mathrm{I.D.} \mathrm{(10-3/4-in.} \mathrm{I.D.)} \mathrm{drill}$ casing above the silica sand filter pack. Because the applied stress occurred within the well screen open to the drill casing above the silica sand pack filter, an equivalent casing radius $\left(r_{c}\right)$ was estimated using the projected stress level $\left(\mathrm{H}_{\mathrm{p}}\right)$ and the slugging rod volume. The projected stress level was determined by linear regression on a semi-log plot of pressure change from static and elapsed time. Downhole testinterval response pressures during testing were monitored with a 0 - to $35-\mathrm{kPa}(0$ - to 5 -psig) pressure transducer placed at a depth of $\sim 70.2 \mathrm{~m}$ bgs. Because of the sensitivity of the low permeable perchedwater aquifer to pressure changes, windy atmospheric pressure conditions likely contributed to observed 
noise within the test data, particularly during the slug withdrawal test when wind gusts increased during the later morning hours. The static depth measurement to the perched-aquifer water table before conducting the slug tests was $68.21 \mathrm{~m}$ bgs.

Both the slug injection and slug withdrawal tests exhibited nonelastic, over-damped (exponentialdecay response) homogeneous-formation behavior, which is indicative of low-to-moderate permeability test-zone conditions. A comparison of the normalized stress, slug-test responses for the injection and withdrawal tests indicated nearly identical behavior. Slug tests exhibiting this type of response behavior can be analyzed quantitatively with homogeneous-formation analysis approaches, as described by Butler (1998). For the homogeneous-formation analysis, the standard type curve method provided estimates of $\mathrm{K}$ ranging between 1.20 to $1.51 \mathrm{~m} /$ day, averaging $1.36 \mathrm{~m} / \mathrm{day}$. This range is comparable to the Bouwer and Rice analysis method, which provides a range of 1.12 to $1.43 \mathrm{~m} /$ day, averaging $1.28 \mathrm{~m} /$ day. Because the type curve analysis method is generally more reliable than the Bouwer and Rice method, the average type curve analysis result of $1.36 \mathrm{~m} /$ day yields the best estimate for this test/depth interval. A selected example of the type curve analysis plots for this test/depth interval is shown in Figure 4.1.

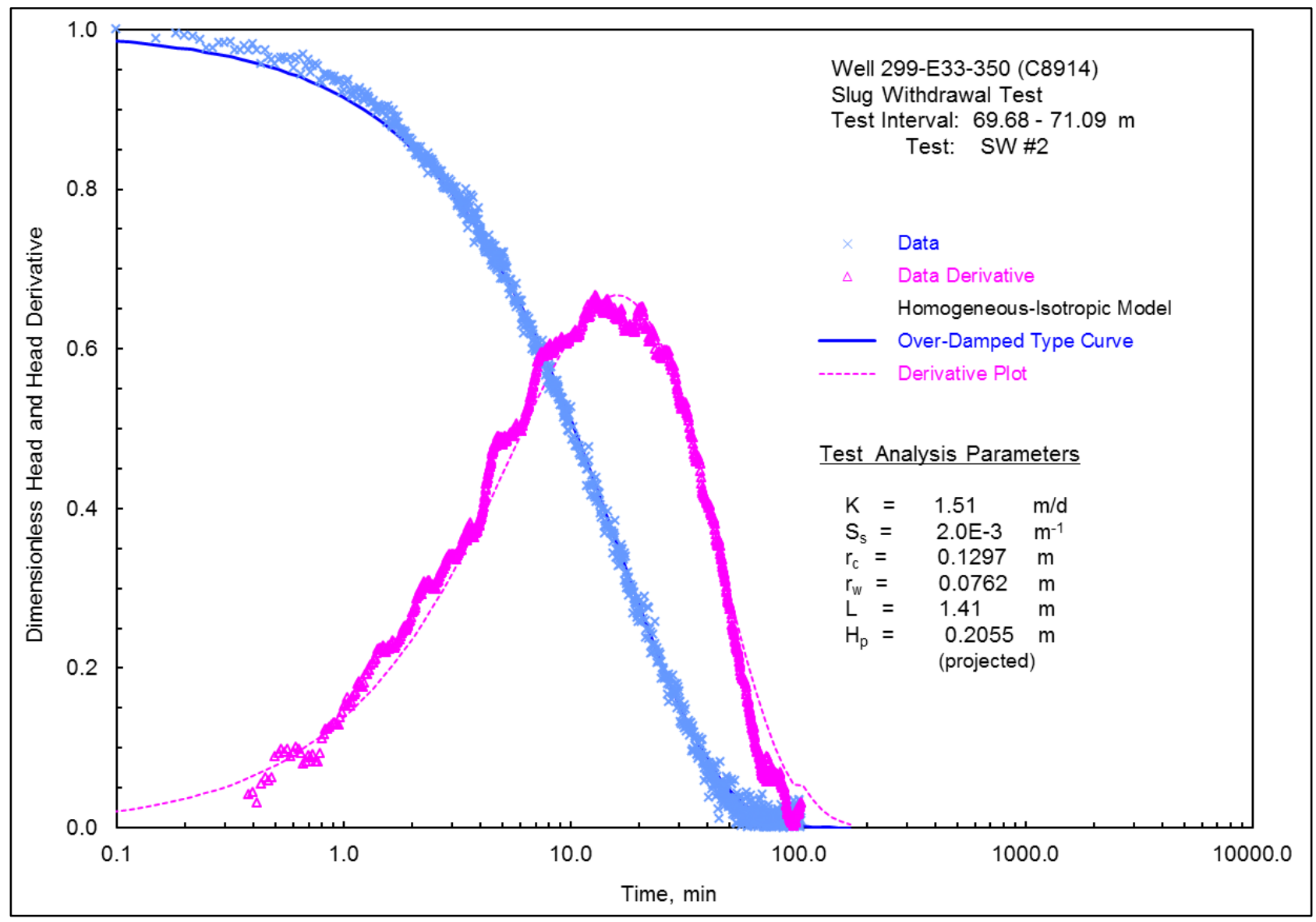

Figure 4.1. Selected Type-Curve Analysis Plot for Zone 1, Well 299-E33-350 (C8914)

\subsubsection{Zone 2 (Depth: 68.24 to $71.09 \mathrm{~m}$ )}

Following slug testing in Zone 1, the borehole annulus was back-filled with 20-40 silica sand filter pack from a depth of 68.64 to $67.88 \mathrm{~m}$ bgs and the 0.2985-m O.D. (11-3/4-in. O.D.) drill casing was back- 
pulled $1.54 \mathrm{~m}$ (i.e., from 69.68 to $68.11 \mathrm{~m} \mathrm{bgs}$ ), exposing the well screen to nearly the entire perchedwater aquifer. This produced a test/depth interval for Zone 2 of 68.24 to $71.09 \mathrm{~m}$ bgs that overlaps Zone 1 within the silty-sand subunit $\mathrm{CCU}_{\mathrm{z} \text { sand. }}$ Surging was performed to develop the exposed section of the well screen and perched water table conditions were allowed to stabilize before initiating the slug tests.

Two slug tests (one injection and one withdrawal test) were conducted at 1502 hours (PST), on March 5, 2014, and at $0723 \mathrm{hr}$ (PST), respectively, on March 6, 2014. However, the slug injection test data cannot be analyzed due to data loss associated with a disconnected wire between the data logger and pressure transducer at elapsed time $7.6<\mathrm{t}<13.2 \mathrm{~min}$. The slugging rod was fully submerged in the water column, with a fully submerged estimated volume of $0.0109 \mathrm{~m}^{3}$. This slug-rod volume imparted a theoretical applied stress level $\left(\mathrm{H}_{\mathrm{o}}\right)$ of $0.594 \mathrm{~m}$ within the 0.152-m (6-in. O.D.) well screen. Downhole test-interval response pressures during testing were monitored with a 0 - to $35-\mathrm{kPa}$ ( 0 - to 5-psig) pressure transducer placed at a depth of $\sim 70.4 \mathrm{~m}$ bgs. The static depth measurement to the perched-aquifer water table before conducting the slug tests was $68.24 \mathrm{~m}$ bgs.

A diagnostic analysis of the slug withdrawal test conducted for this test/depth interval indicates a heterogeneous, composite-formation response condition. This test pattern exhibits a higher permeability, inner-zone response during the initial recovery portion of the test that slowly transitions to a lower permeability response for the surrounding outer-zone formation. The presence of an elastic, highpermeability inner zone reflects an artificially induced condition that was likely attributed to collapse of unconsolidated formation sediments around the well screen as the drill casing was retracted.

As discussed by Spane (1993), slug tests exhibiting linear-response characteristics for heterogeneous formation tests can be analyzed with the homogeneous-formation analysis approaches. For the homogeneous-formation analysis, the type curve method estimates for $\mathrm{K}$ was $0.58 \mathrm{~m} /$ day for the outerzone formation and $2.88 \mathrm{~m} /$ day for the artificially created, higher permeability, inner zone. The Bouwer and Rice method yielded very comparable, but slightly lower estimates for $\mathrm{K}-0.40 \mathrm{~m} / \mathrm{day}$ for the outerzone formation and $2.55 \mathrm{~m} /$ day for the inner zone. Because the type curve analysis method is generally more reliable than the Bouwer and Rice method, the type curve analysis result of $0.58 \mathrm{~m} /$ day for the outer zone and $2.88 \mathrm{~m} /$ day for the inner zone yields the best estimates for this test/depth interval. Selected examples of the diagnostic and type curve test-analysis plots for this test/depth interval are shown in Figure 4.2 and Figure 4.4 (a, b), respectively. 


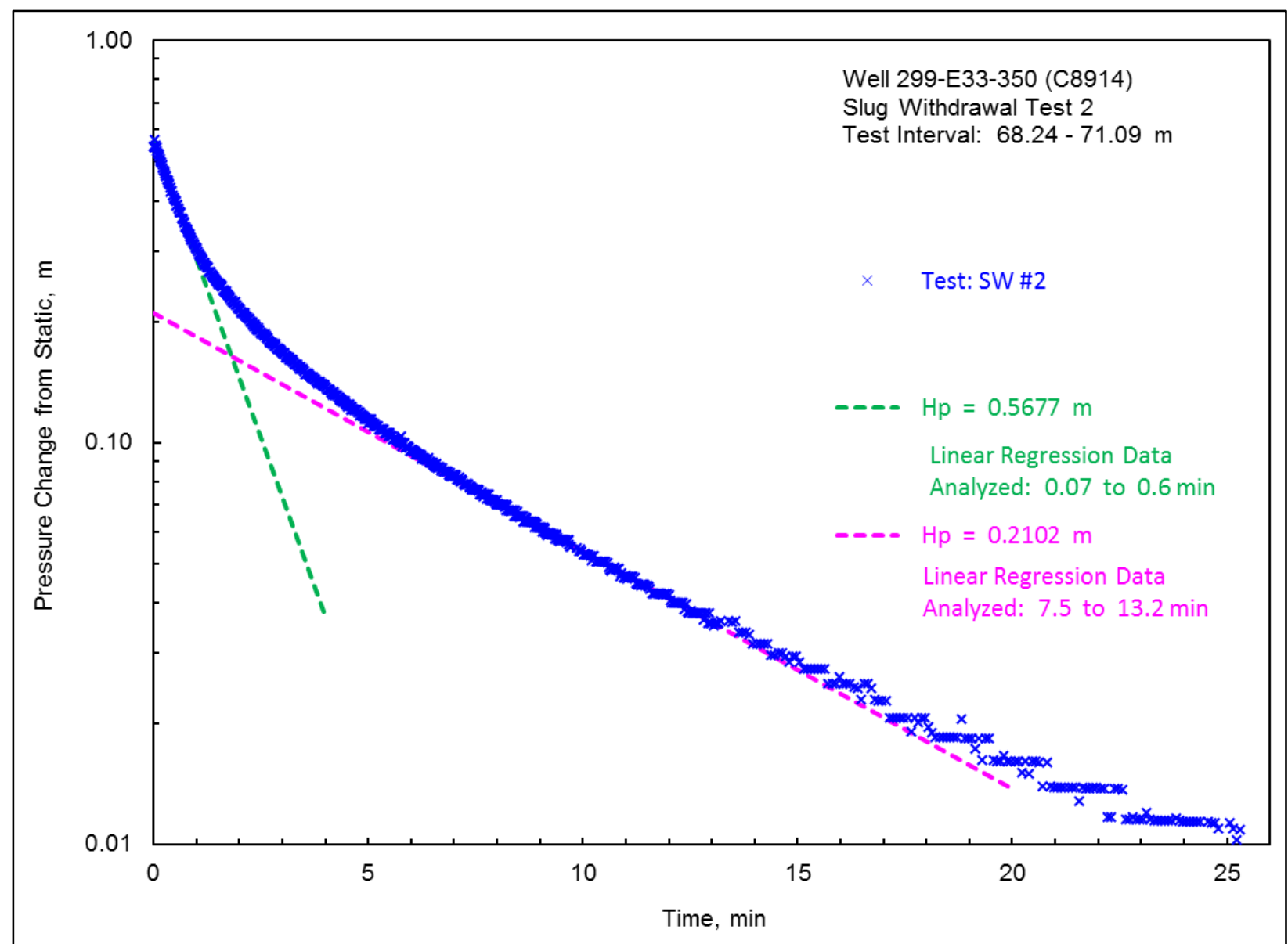

Figure 4.2. Selected Bouwer and Rice Diagnostic Analysis Plot for Zone 2, Well 299-E33-350 (C8914) 


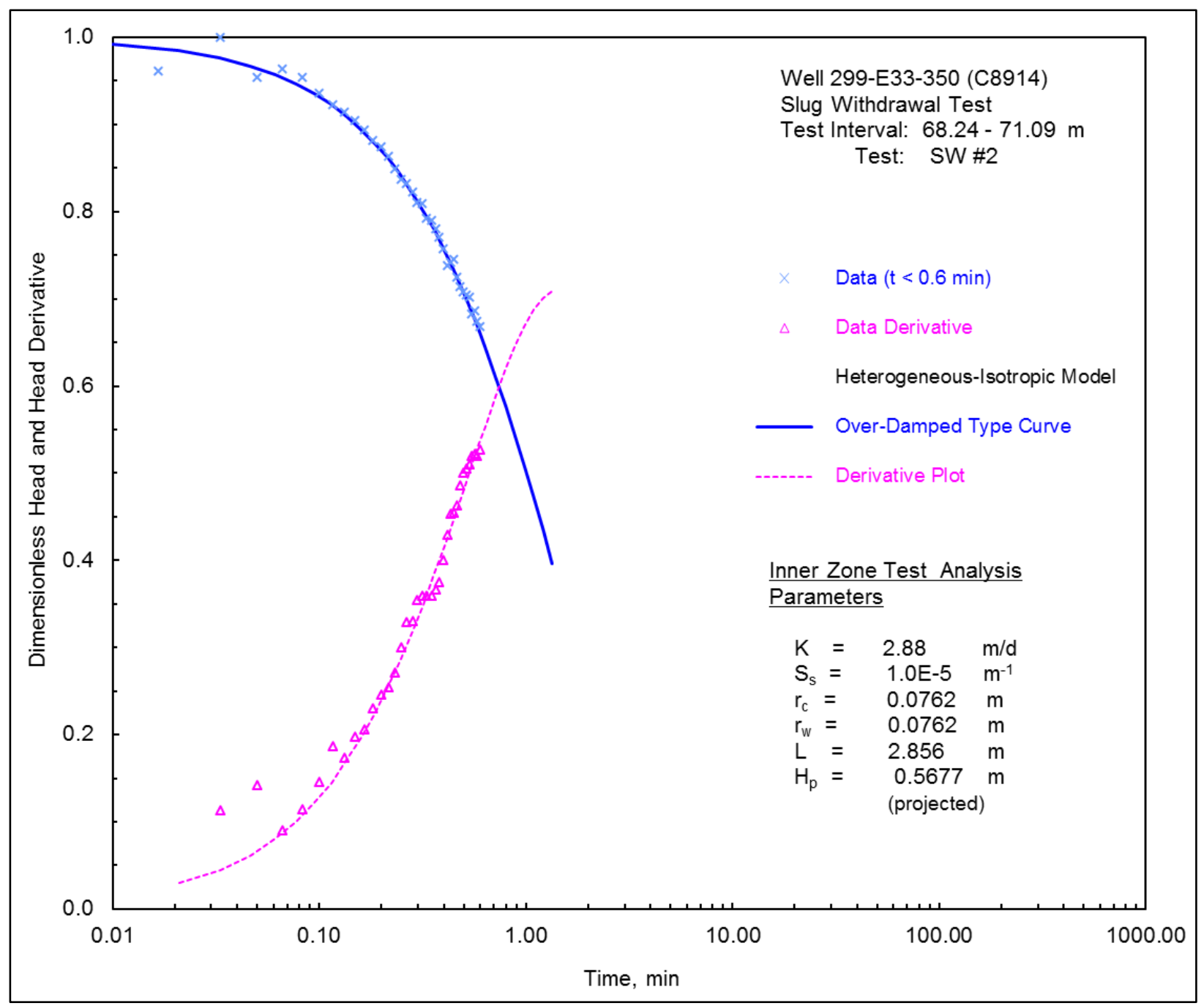

(a)

Figure 4.3. Selected Type-Curve Analysis Plots, Zone 2, Well 299-E33-350, for (a) the Artificially Created, High-Permeability Inner-Zone and (b) the Lower Permeability Outer-Zone Formation 


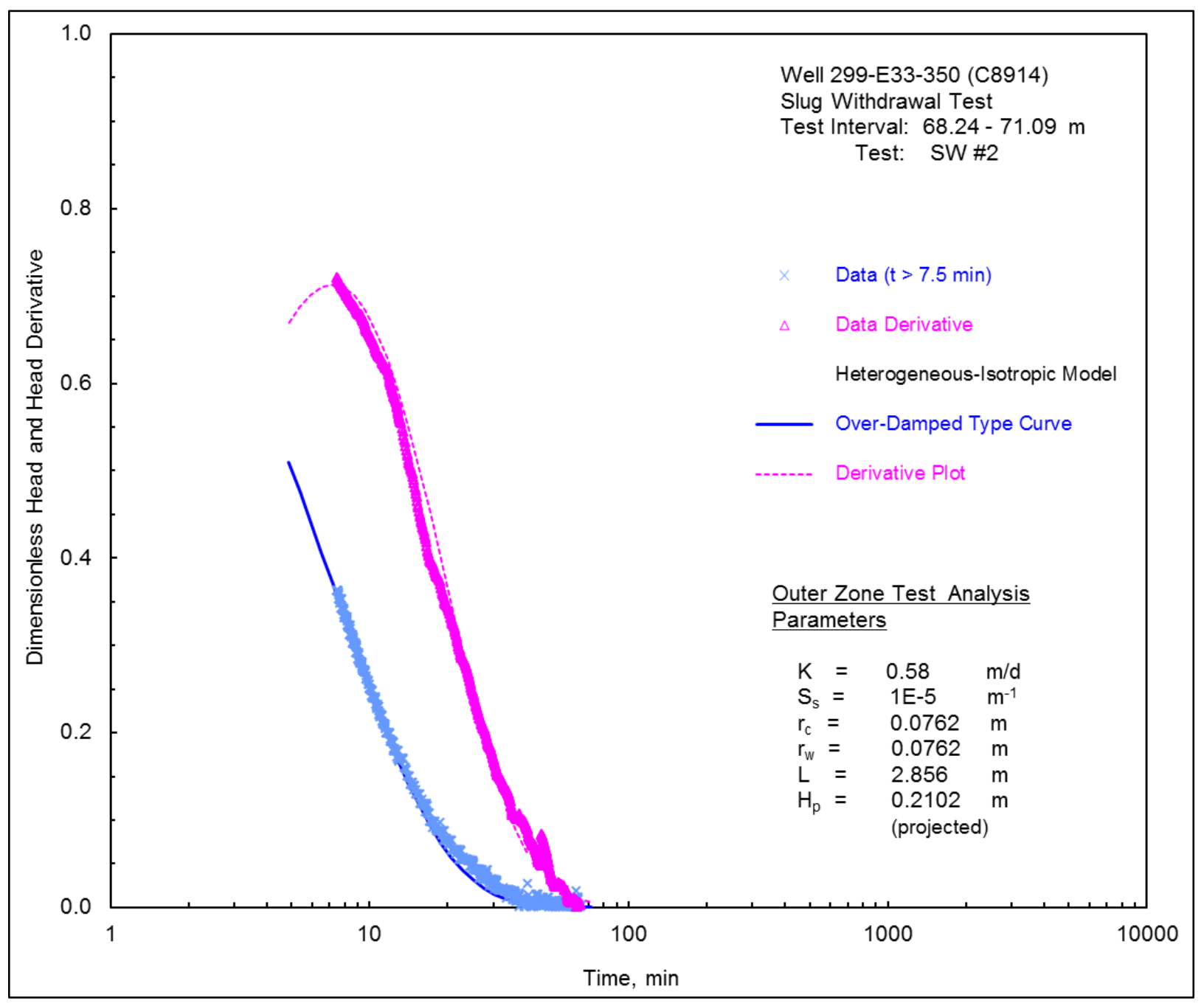

(b)

Figure 4.4. (contd)

\subsection{Well 299-E33-351 (C8915)}

The drilling of B-Complex well 299-E33-351 reached a total depth of $71.32 \mathrm{~m}$ bgs. The lower silt subunit $\left(\mathrm{CCU}_{\mathrm{z} \text { lower }}\right)$ of the fine-grained Cold Creek unit $\left(\mathrm{CCU}_{\mathrm{z}}\right)$ was encountered at a depth of $71.08 \mathrm{~m}$ bgs, which represents the bottom boundary of the perched-water aquifer at this location. The $\sim 2.9-\mathrm{m}$ thick perched-water aquifer occurs within the silty-sand subunit $\left(\mathrm{CCU}_{\mathrm{z} \text { sand }}\right)$, which overlies the $\mathrm{CCU}_{\mathrm{z} \text { lower }}$. Two test-depth intervals were tested at this borehole location during well completion: Zone $1=69.22$ to $70.97 \mathrm{~m}$ bgs and Zone $2=68.17$ to $70.97 \mathrm{~m}$ bgs. The static water-level depth during hydrologic testing ranged between 68.17 and $68.24 \mathrm{~m}$ bgs.

\subsubsection{Zone 1 (Depth: 69.22 to $70.97 \mathrm{~m}$ )}

The 40-slot, 6-in. stainless steel well-screen assembly was lowered to the bottom of the borehole at a depth of $71.08 \mathrm{~m}$ bgs. The borehole was back-filled with 20-40 mesh silica sand filter pack to a depth of $68.55 \mathrm{~m}$ bgs and the 0.2731-m O.D. (10-3/4-in. O.D.) drill casing was back-pulled $1.80 \mathrm{~m}$ (i.e., from 71.02 
to $69.22 \mathrm{~m} \mathrm{bgs}$ ), exposing the lower $1.75 \mathrm{~m}$ of the $3.05-\mathrm{m}$ long well screen to the perched-water aquifer. This produced a test/depth interval for Zone 1 of 69.22 to $70.97 \mathrm{~m} \mathrm{bgs}$ within the lower part of the siltysand subunit $\mathrm{CCU}_{\mathrm{z} \text { sand }}$. Surging was performed to develop the exposed section of the well screen and perched water table conditions were allowed to stabilize before initiating the slug tests.

Two slug tests (one injection and one withdrawal test) were conducted at 1045 hours and 1219 hours (PST), respectively, on February 26, 2014. The slugging rod was partially submerged in the watercolumn, with a partially submerged estimated volume of $0.0036 \mathrm{~m}^{3}$. This slug-rod volume imparted a theoretical applied stress level $\left(\mathrm{H}_{\mathrm{o}}\right)$ of $0.199 \mathrm{~m}$ within the $0.237-\mathrm{m}$ I.D. (9-1/3-in. I.D.) drill casing above the silica sand filter pack. The slugging rod was partially submerged instead of fully submerged to avoid the occurrence of initial stress-level displacement $\left(\mathrm{H}_{\mathrm{o}}\right)$ across the top of the silica sand pack filter during the slug withdrawal test. Because the applied stress occurred within the well screen open to the drill casing above the silica sand pack filter, an equivalent casing radius $\left(\mathrm{r}_{\mathrm{c}}\right)$ was estimated using the projected stress level $\mathrm{H}_{\mathrm{p}}$ and the slugging rod volume. The projected stress level was determined by linear regression on a semi-log plot of pressure change from static and elapsed time. Downhole test-interval response pressures during testing were monitored with a 0 - to $35-\mathrm{kPa}$ ( 0 - to 5-psig) pressure transducer placed at a depth of $\sim 70.0 \mathrm{~m}$ bgs. The static depth measurement to the perched-aquifer water table before conducting the slug tests was $68.24 \mathrm{~m}$ bgs.

Both the slug injection and slug withdrawal tests exhibited elastic, over-damped (exponential-decay response) homogeneous-formation behavior, which is indicative of low-to-moderate permeability testzone conditions. A comparison of the normalized stress, slug-test responses for the injection and withdrawal tests indicated nearly identical behavior. Slug tests exhibiting this type of response behavior can be analyzed quantitatively with homogeneous-formation analysis approaches, as described by Butler (1998). For the homogeneous-formation analysis, the standard type curve method provided estimates of $\mathrm{K}$ ranging between 0.62 to $0.82 \mathrm{~m} /$ day, averaging $0.72 \mathrm{~m} /$ day. This range is comparable to the Bouwer and Rice analysis method results, which provides a range of 0.57 to $0.67 \mathrm{~m} /$ day, averaging $0.62 \mathrm{~m} /$ day. Because the type curve analysis method is generally more reliable than the Bouwer and Rice method, the average type curve analysis result of $0.72 \mathrm{~m} /$ day yields the best estimate for this test/depth interval. A selected example of the type curve analysis plots for this test/depth interval is shown in Figure 4.5. 


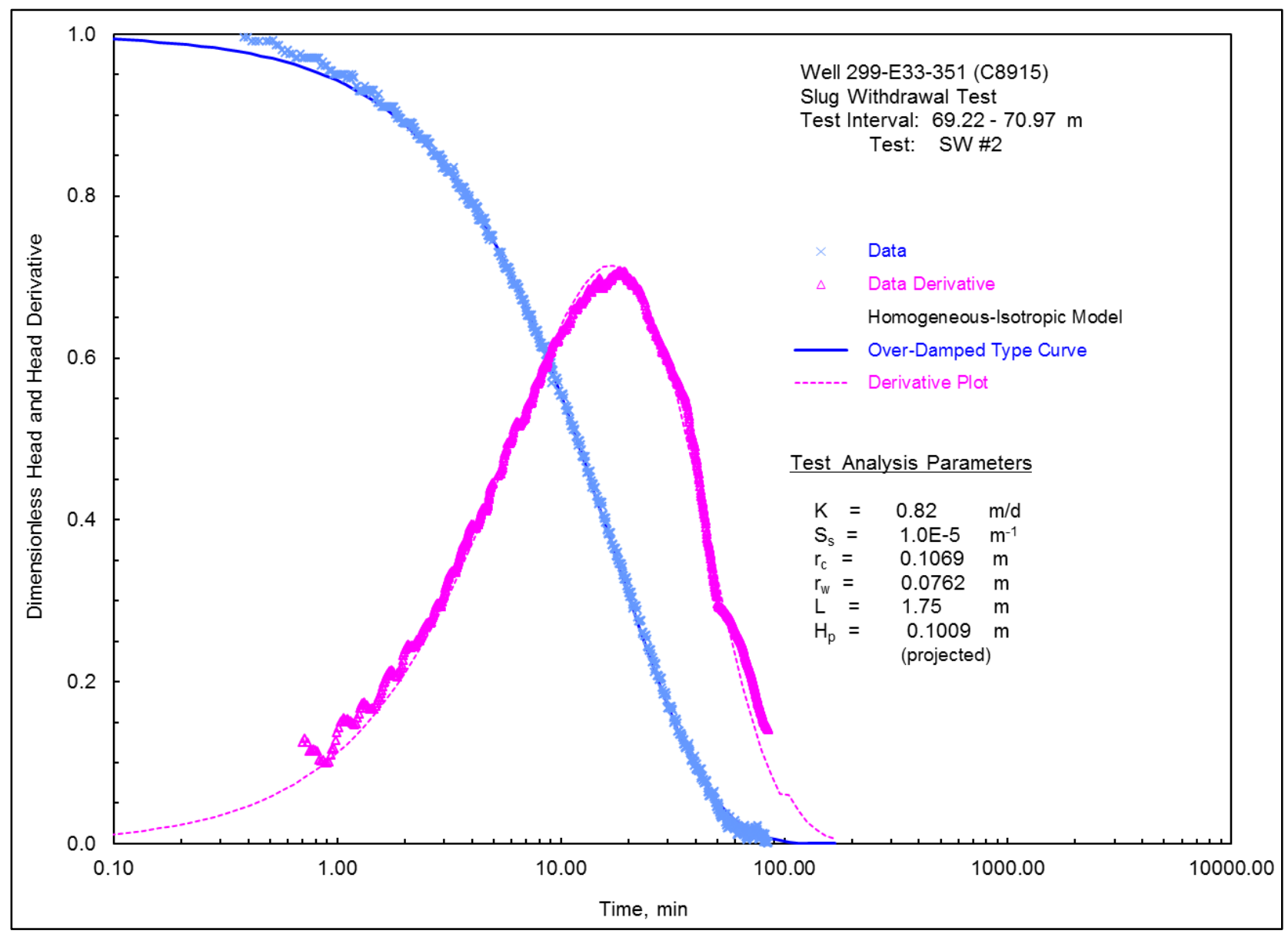

Figure 4.5. Selected Type-Curve Analysis Plot for Zone 1, Well 299-E33-351 (C8915)

\subsubsection{Zone 2 (Depth: 68.17 to $70.97 \mathrm{~m}$ )}

After slug testing in Zone 1, the borehole was back-filled with 20-40 silica sand filter pack from a depth of 68.55 to $66.45 \mathrm{~m}$ bgs and construction of the well continued until it was nearly completed before Zone 2 was tested. The 0.2731-m O.D. (10-3/4-in. O.D.) drill casing was removed from the borehole, exposing the 3.05-m-long well screen to nearly the entire perched-water aquifer. This produced a test/depth interval for Zone 2 of 68.17 to $70.97 \mathrm{~m}$ bgs that overlaps Zone 1 within the silty-sand subunit $\mathrm{CCU}_{\mathrm{z} \text { sand. }}$. Surging was performed to develop the exposed section of the well screen, and perched water table conditions were allowed to stabilize before initiating the slug tests.

Two slug tests (one injection and one withdrawal test) were conducted at 0835 hours (PST) and 1031 hours (PST), respectively, on March 6, 2014. The slugging rod was fully submerged in the water column, with a fully submerged estimated volume of $0.0109 \mathrm{~m}^{3}$. This slug-rod volume imparted a theoretical applied stress level $\left(\mathrm{H}_{\mathrm{o}}\right)$ of $0.594 \mathrm{~m}$ within the $0.152-\mathrm{m}$ (6-in. O.D.) well screen. Downhole test-interval response pressures during testing were monitored with a 0 - to $69-\mathrm{kPa}$ (0- to $10-\mathrm{psig}$ ) pressure transducer placed at a depth of $\sim 69.8 \mathrm{~m}$ bgs. The static depth measurement to the perched-aquifer water table before conducting the slug tests was $68.17 \mathrm{~m}$ bgs. 
Both the slug injection and slug withdrawal tests exhibited elastic, over-damped (exponential-decay response) homogeneous-formation behavior, which is indicative of low-to-moderate permeability testzone conditions. A comparison of the normalized stress, slug-test responses for the injection and withdrawal tests indicated similar behavior, with only a slight delay in the slug withdrawal data response. Each of the slug injection and withdrawal test responses also indicates an elastic (concave-upward) response displayed on a Bouwer and Rice analysis plot, as shown by a selected plot in Figure 4.6. Analysis of the elastic response requires that the normalized head segment of 0.2 to 0.3 be used when applying the Bouwer and Rice (1976) method, as recommended by Butler $(1996,1998)$. For the Bouwer and Rice method, estimates for K ranged from 1.15 to $1.47 \mathrm{~m} /$ day, averaging $1.31 \mathrm{~m} /$ day. The Bouwer and Rice derived K estimates compare favorably with results obtained using the type curve method, with $\mathrm{K}$ ranging from 1.15 to $1.44 \mathrm{~m} /$ day, averaging $1.30 \mathrm{~m} /$ day. Because the type curve analysis method is generally more reliable than the Bouwer and Rice method, the average type curve analysis result of $1.30 \mathrm{~m} /$ day yields the best estimate for this test/depth interval. A selected example of the type curve analysis plots for this test/depth interval is shown in Figure 4.7.

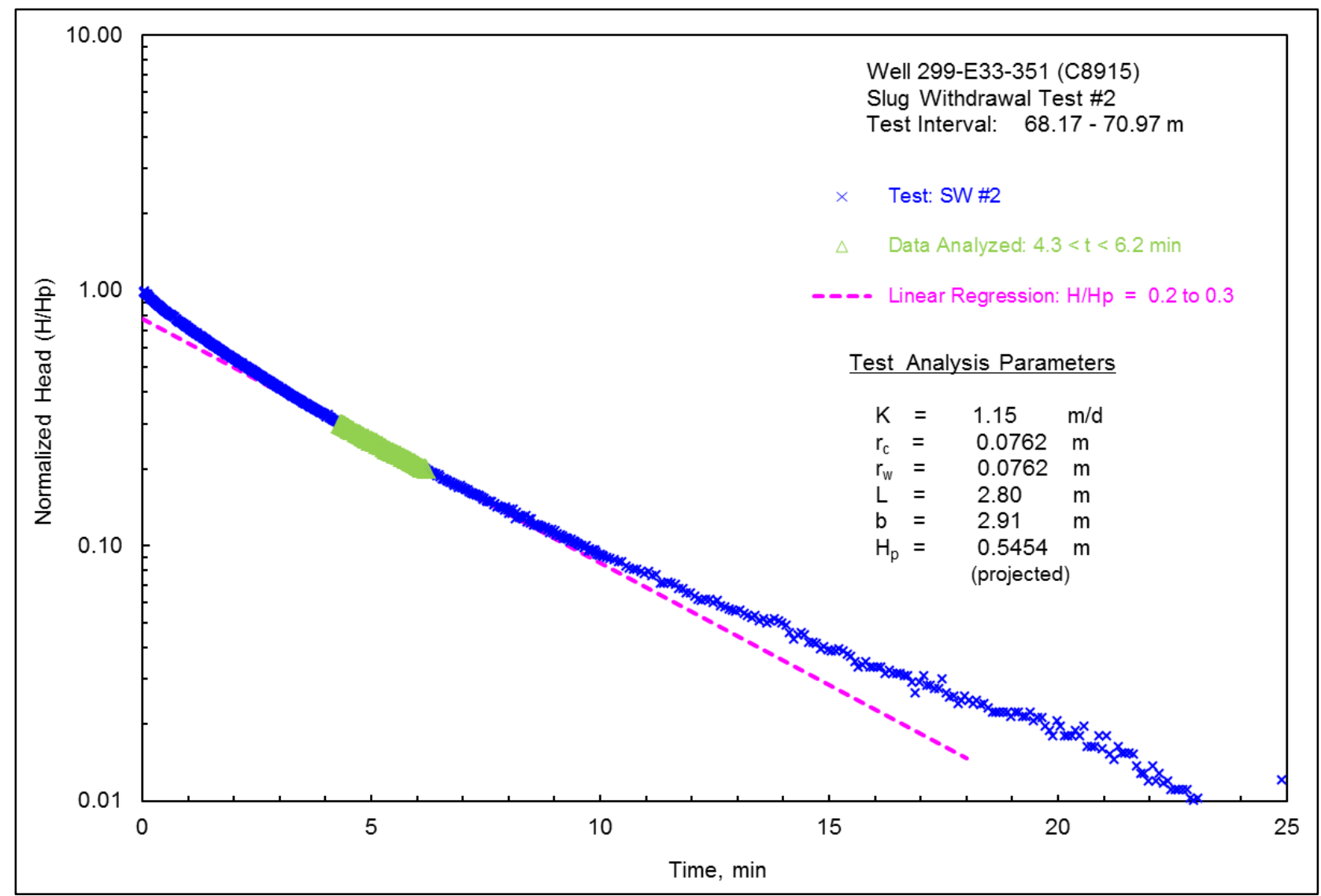

Figure 4.6. Selected Bouwer and Rice Analysis Plot for Zone 2, Well 299-E33-351 (C8915) 


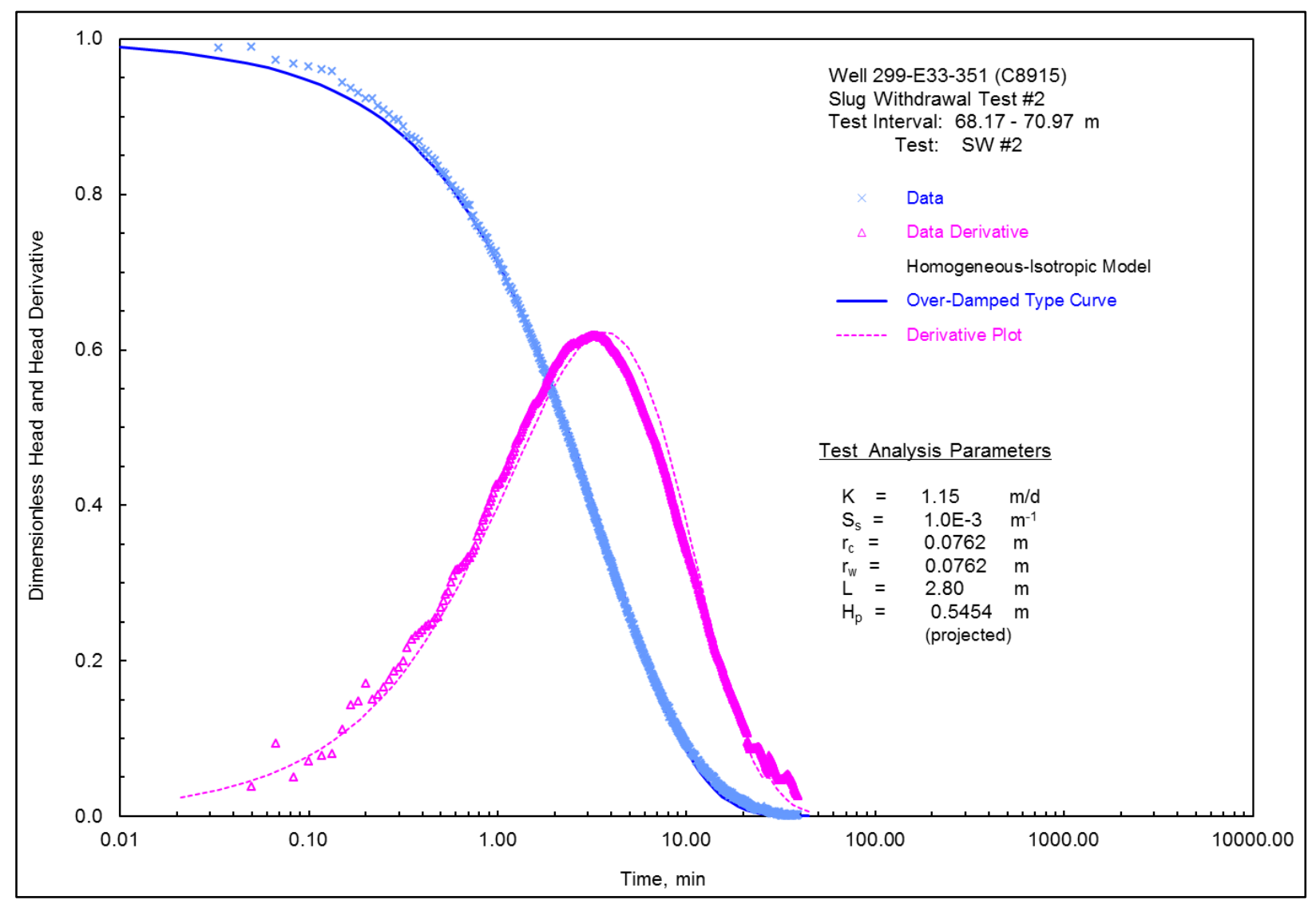

Figure 4.7. Selected Type-Curve Analysis Plot for Zone 2, Well 299-E33-351 (C8915) 


\subsection{Hydraulic Property Depth Profile Comparison}

Figure 5.1 and Figure 5.2 show depth profiles of the vertical distribution of average horizontal hydraulic-conductivity values for the B-Complex wells 299-E33-350 and 299-E33-351, respectively, as determined from slug-test characterization. For comparison purposes, vertical hydraulic conductivity obtained from intact laboratory core analyses collected from the respective depths also are shown in the figures. The distributions for Zones 1, 2, and 3 are based on test/depth slug-test characterization type curve results summarized in Table 4.1 and Table 4.2, and they represent average horizontal hydraulicconductivity values (i.e., best estimate) determined using the type curve analysis method. The perchedwater aquifer at these well locations lies within $\mathrm{CCU}_{\mathrm{z} \text { sand }}$ subunit of the $\mathrm{CCU}$ between the perched water table and the top of the underlying lower perching silt subunit, $\mathrm{CCU}_{\mathrm{z} \text { lower }}$. Because the test/depth interval of Zone 2 overlaps the test/depth interval of Zone 1 at each well location, the difference in the transmissivity (T) between these two zones (i.e., hydraulic conductivity multiplied by the test-interval thickness) can be inferred to represent transmissivity within the upper part of the perched-water aquifer, defined here as Zone 3, using the superposition principle (Reilly et al. 1987). The hydraulic conductivity of Zone 3 can be estimated by dividing the calculated transmissivity of this zone by the Zone 3 thickness. These estimates of $\mathrm{T}$ and $\mathrm{K}$ are summarized in Table 5.1. As indicated, the vertical profile information suggests a relatively uniform horizontal hydraulic-conductivity range within the perched aquifer, with approximately one order of magnitude or less variability in hydraulic conductivity. These ranges of $\mathrm{T}$ and $\mathrm{K}$ for the $\mathrm{CCU}_{\mathrm{z} \text { sand }}$ in Table 5.1 are within the range expected for silty-sand materials. Based on the range of $\mathrm{K}$ values provided by Heath (1983) and an equivalent test/depth interval thickness range (i.e., 1.05 to $2.85 \mathrm{~m}$ ), T ranges from approximately 0.1 to $30 \mathrm{~m}^{2} /$ day and $\mathrm{K}$ ranges from approximately 0.1 to $10 \mathrm{~m} /$ day for silty-sand material.

It should be noted that the composite transmissivity of the perched-water aquifer at well 299-E33-351 is more than two times the transmissivity at well 299-E33-350. This difference in transmissivity at these perched-water aquifer well locations is consistent with the uranium plume distribution for the underlying unconfined aquifer shown in Figure 1.1; that is, higher unconfined aquifer uranium concentrations are in the same location as higher perched-water aquifer transmissivity. Figure 1.1 indicates that well 299-E33351 is located within the plume area where the uranium concentrations $\geq 300 \mu \mathrm{g} / \mathrm{L}$, while well 299-E33350 is located within the plume area where the concentrations $\geq 30 \mu \mathrm{g} / \mathrm{L}$ and $<300 \mu \mathrm{g} / \mathrm{L}$.

For comparison, depth profiles for geometric average vertical hydraulic-conductivity values of intact core samples collected from the same boreholes also are shown in Figure 5.1 and Figure 5.2. These core samples represent a 0.15 -m depth interval within the upper part of the $\mathrm{CCU}_{\mathrm{z} \text { sand }}$ and the overlying upper silt subunit $\left(\mathrm{CCU}_{\mathrm{z} \text { upper }}\right)$. Vertical hydraulic-conductivity values were estimated using laboratory permeability tests (i.e., constant-head test method) under saturated conditions. The constant-head test method is described by the American Society for Testing and Materials (ASTM 2010). The profile comparison indicates vertical hydraulic conductivity that is lower than horizontal hydraulic conductivity by approximately one to three orders of magnitude within the upper part of the $\mathrm{CCU}_{\mathrm{z} \text { sand. }}$ An even lower vertical hydraulic conductivity measured on core samples from the $\mathrm{CCU}_{\mathrm{z} \text { upper }}$ indicates a lower permeability within this subunit compared to the underlying $\mathrm{CCU}_{\mathrm{z} \text { sand }}$.

Laboratory permeability tests (i.e., falling-head permeability tests) under saturated conditions were conducted on intact vadose zone core samples from a single borehole at the nearby BY Cribs in the B-Complex Area. These laboratory test results (not shown), which are reflective of vertical hydraulic 
properties, were reported to range from 1.8E-3 to 6.1E-2 m/day for the $\mathrm{CCU}_{\mathrm{z}}$ (Kahleel 2007; Serne et al. 2010).

The geometric average vertical hydraulic conductivity of intact core samples collected at the same boreholes used for the slug tests from the $0.15-\mathrm{m}$ intervals within the upper part of the $\mathrm{CCU}_{\mathrm{z} \text { sand }}$ ranged from $0.0022 \mathrm{~m} /$ day for well 299-E33-350 to $0.134 \mathrm{~m}$ /day for well 299-E33-351 (CHPRC 2014). This range yields a geometric mean of $0.017 \mathrm{~m} /$ day for vertical hydraulic conductivity within the upper part of the $\mathrm{CCU}_{\mathrm{z} \text { sand }}$. Comparison of this mean with the geometric mean of $0.64 \mathrm{~m} /$ day for the inferred horizontal hydraulic conductivity (i.e., range of 0.18 to $2.27 \mathrm{~m} /$ day) indicates a vertical anisotropy of approximately 0.026 for the upper half of the perched $\mathrm{CCU}_{\mathrm{z} \text { sand. }}$ This vertical anisotropy ratio falls within the range expected for fine-grained silty-sand materials. Todd (1980) and Deming (2002) reported vertical anisotropy values typically range between of 0.1 to 1.0 for alluvial sediments, but can range as low as 0.01 to 0.001 .

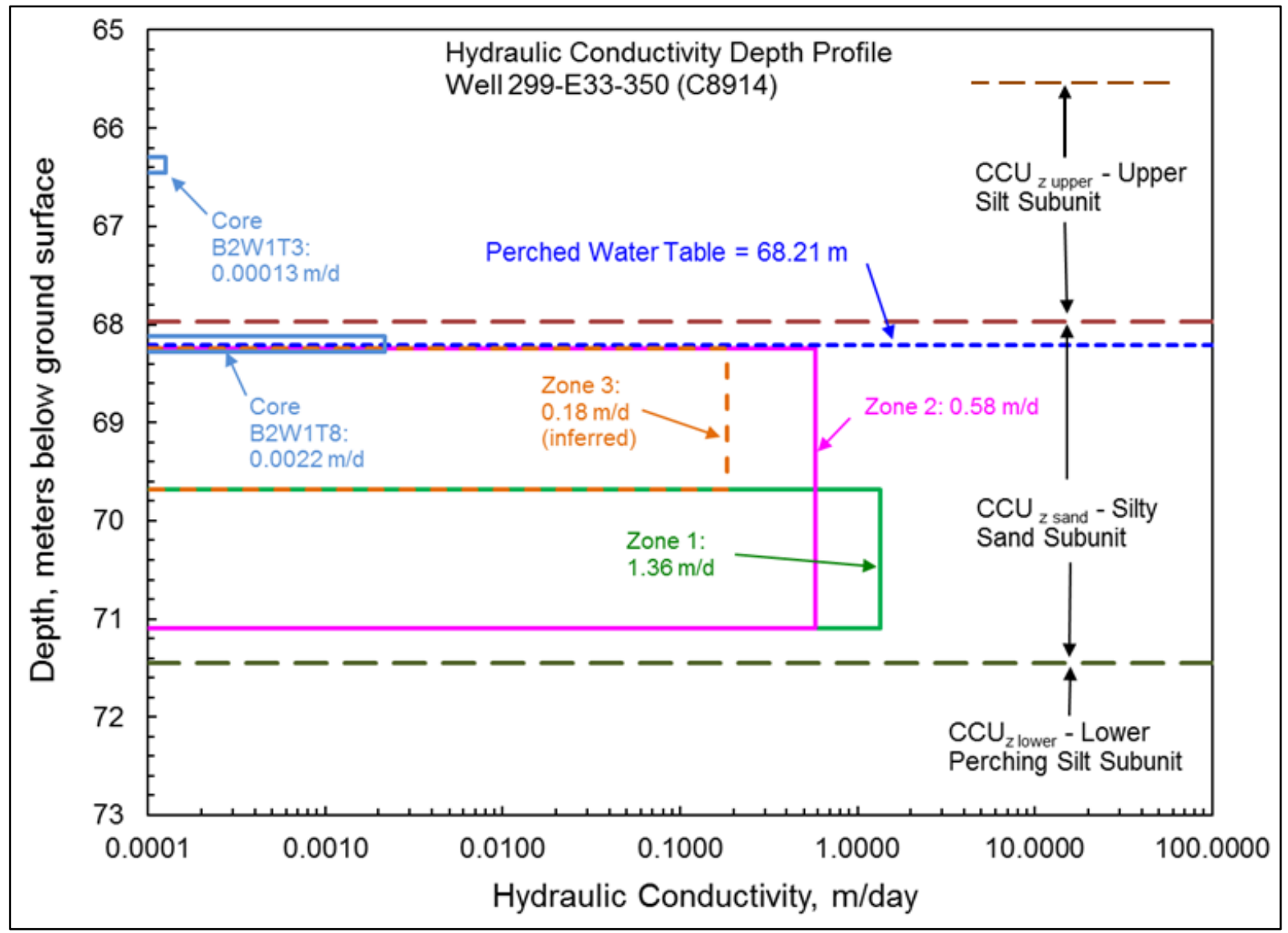

Figure 5.1. Hydraulic-Conductivity Depth Profile for Well 299-E33-350 (C8914) 


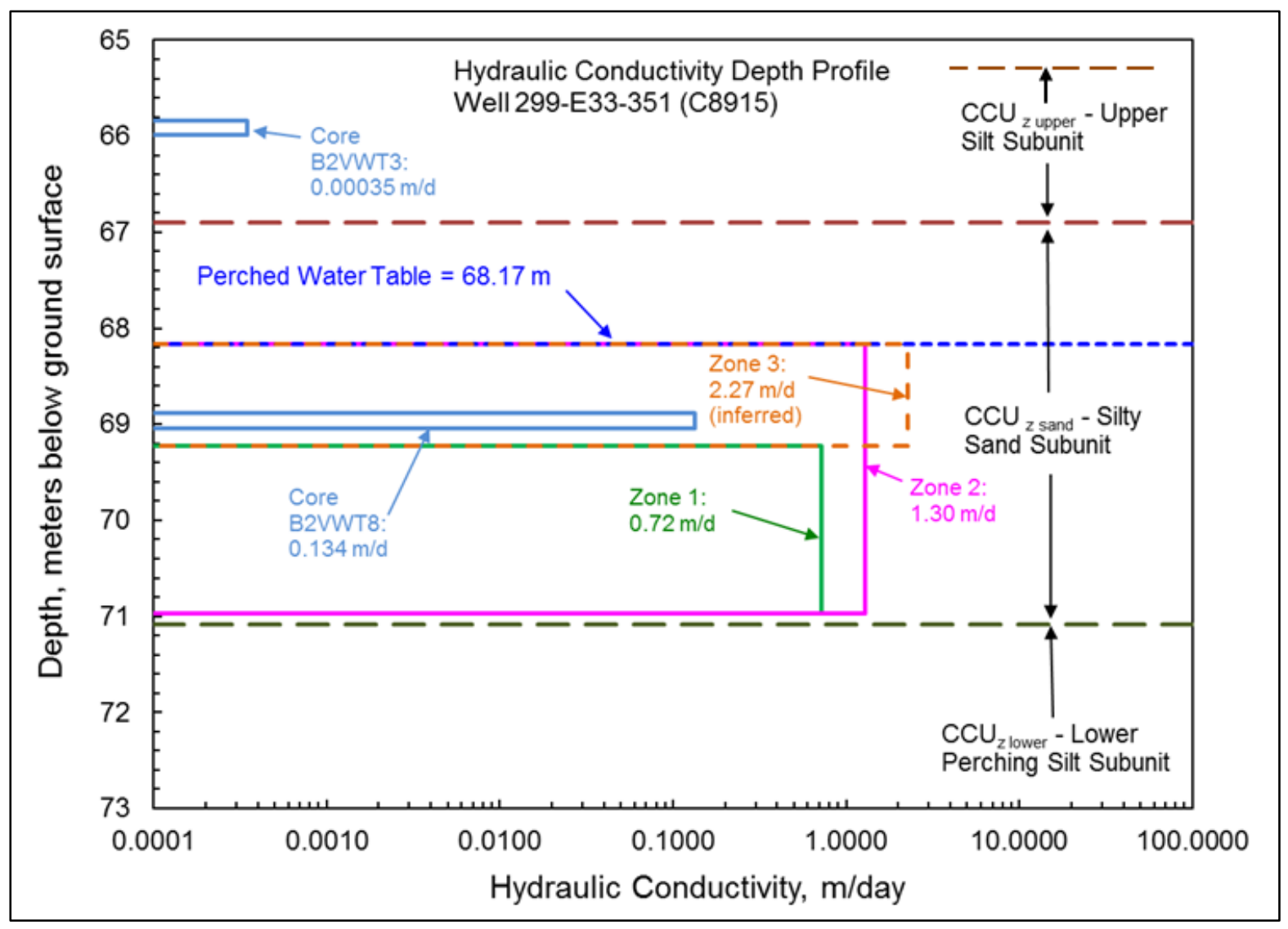

Figure 5.2. Hydraulic-Conductivity Depth Profile for Well 299-E33-351 (C8915)

Table 5.1. Test-Zone Estimates of Transmissivity and Hydraulic Conductivity based on Average TypeCurve Slug-Test Analysis Results for the Silty-Sand Subunit of the Cold Creek Fine-Grained Unit

\begin{tabular}{|c|c|c|c|c|}
\hline $\begin{array}{l}\text { Test Well Number } \\
\text { (Borehole I.D.) }\end{array}$ & Test Zone & $\begin{array}{c}\text { Transmissivity, } \mathrm{T}^{(\mathrm{a})} \\
\left(\mathrm{m}^{2} / \text { day }\right)\end{array}$ & $\begin{array}{l}\text { Test/Depth } \\
\text { Interval, } \\
\text { L (m) }\end{array}$ & $\begin{array}{c}\text { Hydraulic Conductivity, } \\
\mathrm{K}_{\mathrm{h},,} \text { (a) } \\
(\mathrm{m} / \text { day })\end{array}$ \\
\hline \multirow{3}{*}{$\begin{array}{l}\text { 299-E33-350 } \\
\text { (C8914) }\end{array}$} & $\begin{array}{l}\text { Zone } 1 \text { (lower } \\
\text { half) }\end{array}$ & 1.92 & $\begin{array}{c}69.68-71.09 \\
(1.41)\end{array}$ & 1.36 \\
\hline & $\begin{array}{c}\text { Zone } 2 \\
\text { (nearly full } \\
\text { thickness) }\end{array}$ & 1.65 & $\begin{array}{c}68.24-71.09 \\
(2.85)\end{array}$ & 0.58 \\
\hline & $\begin{array}{c}\text { Zone } 3 \text { (upper } \\
\text { half) }\end{array}$ & 0.27 (inferred) & $\begin{array}{c}68.24-69.68 \\
(1.44)\end{array}$ & 0.18 (inferred) \\
\hline \multirow{3}{*}{$\begin{array}{l}\text { 299-E33-351 } \\
\quad(\mathrm{C} 8915)\end{array}$} & $\begin{array}{l}\text { Zone } 1 \text { (lower } \\
\text { half) }\end{array}$ & 1.26 & $\begin{array}{c}69.22-70.97 \\
(1.75)\end{array}$ & 0.72 \\
\hline & $\begin{array}{l}\text { Zone } 2 \\
\text { (nearly full } \\
\text { thickness) }\end{array}$ & 3.64 & $\begin{array}{c}68.17-70.97 \\
(2.80)\end{array}$ & 1.30 \\
\hline & $\begin{array}{c}\text { Zone } 3 \text { (upper } \\
\text { half) }\end{array}$ & 2.38 (inferred) & $\begin{array}{c}68.17-69.22 \\
(1.05)\end{array}$ & 2.27 (inferred) \\
\hline
\end{tabular}

(a) Assumed to be uniform within the zone section. 


\subsection{Conclusions}

After reaching total drill depth, slug-test analysis results were obtained for four test/depth intervals within the B-Complex Area perched-water aquifer during the construction of wells 299-E33-350 and 299-E33-351. The perched-water aquifer was characterized after the final well-screen/casing was installed and partially completed with a sand filter pack while the temporary drill casing was back-pulled, exposing the well screen to the formation.

Results from the B-Complex Area borehole slug tests provide a general vertical distribution profile of hydraulic characterization information for approximately the lower and upper half of the perched-water aquifer. Because the nearly full perched-zone thickness test intervals overlap the lower-half test intervals, results of slug tests conducted within these test intervals were used to infer hydraulic characterization information for the upper half of the perched aquifer using the superposition principle. The perchedwater aquifer lies within the silty-sand subunit $\left(\mathrm{CCU}_{\mathrm{z} \text { sand }}\right)$ of the Cold Creek fine-grained unit $\left(\mathrm{CCU}_{\mathrm{z}}\right)$. These slug-test analysis results represent the first known in situ field-scale, hydraulic property estimates for the Cold Creek fine-grained unit at the Hanford Site.

All test/depth intervals within the $\mathrm{CCU}_{\mathrm{z} \text { sand }}$ exhibit exponential-decay (over-damped) slug-test response behavior. This type of slug-test response pattern is indicative of test intervals with low to medium permeability. For test/depth intervals within the lower half of the perched $\mathrm{CCU}_{\mathrm{z} \text { sand, }}$, analyses indicated a best estimate average range for transmissivity of 1.26 to $1.92 \mathrm{~m}^{2} /$ day for the four slug tests (two injection and two withdrawal slug tests) conducted within this zone. This average range of transmissivity yields a best estimate average range for hydraulic conductivity of 0.72 to $1.36 \mathrm{~m} /$ day for the lower half of the perched $\mathrm{CCU}_{\mathrm{z} \text { sand }}$ at these two well locations.

For test/depth intervals that covered close to the full thickness of the perched-water aquifer $\left(\mathrm{CCU}_{\mathrm{z} \text { sand }}\right)$, analyses indicated a best estimate average range for transmissivity of 1.65 to $3.64 \mathrm{~m}^{2} /$ day for the three slug tests (one injection and two withdrawal tests) conducted within this zone. This average range of transmissivity yields a best estimate average range for hydraulic conductivity of 0.58 to $1.30 \mathrm{~m} /$ day for the full thickness of the perched $\mathrm{CCU}_{\mathrm{z} \text { sand }}$ at these two well locations. Applying the principle of superposition to the best estimate average transmissivity values for the lower half and nearly full thickness test intervals of the perched aquifer, transmissivity was inferred to range from 0.27 to $2.38 \mathrm{~m}^{2} /$ day and hydraulic conductivity was inferred to range from 0.18 to $2.27 \mathrm{~m}$ /day for the upper half of the perched $\mathrm{CCU}_{\mathrm{z} \text { sand. }}$. These estimates, which assume uniform hydraulic conductivity across each individual test/depth interval, are representative of the silty-sand subunit, $\mathrm{CCU}_{\mathrm{z} \text { sand. }}$ Estimates of transmissivity and hydraulic conductivity for all test/depth intervals within the perched $\mathrm{CCU}_{\mathrm{z} \text { sand }}$ are within the approximate range of transmissivity ( 0.1 to $30 \mathrm{~m}^{2} /$ day) and hydraulic conductivity ( 0.1 to 10 $\mathrm{m} /$ day) values expected for silty-sand material with an equivalent test/depth interval thickness of 1.05 to $2.85 \mathrm{~m}$.

The geometric average vertical hydraulic conductivity of intact core samples collected from $0.15-\mathrm{m}$ intervals within the upper part of the $\mathrm{CCU}_{z \text { sand }}$ was $0.017 \mathrm{~m} /$ day (CHPRC 2014). Comparison of this mean with the geometric mean of $0.64 \mathrm{~m} /$ day for the inferred horizontal hydraulic conductivity indicates a vertical anisotropy ratio of approximately 0.026 for the upper half of the perched $\mathrm{CCU}_{\mathrm{z} \text { sand. }}$ This vertical anisotropy ratio for the $\mathrm{CCU}_{\mathrm{z} \text { sand }}$ is within the range expected for silty-sand materials. 
The composite transmissivity $\left(3.64 \mathrm{~m}^{2} / \mathrm{d}\right)$ of the perched-water aquifer at well 299-E33-351 is more than two times the transmissivity of $1.65 \mathrm{~m}^{2} / \mathrm{d}$ at well 299-E33-350. The higher perched-water aquifer transmissivity is consistent with the higher uranium concentrations $\geq 300 \mu \mathrm{g} / \mathrm{L}$ within the underlying unconfined aquifer, while the lower transmissivity within the perched-water aquifer is consistent with lower unconfined aquifer uranium concentrations $\geq 30 \mu \mathrm{g} / \mathrm{L}$ and $<300 \mu \mathrm{g} / \mathrm{L}$. 


\subsection{References}

ASTM (American Society for Testing and Materials). 2010. Standard Test Methods for Measurement of Hydraulic Conductivity of Saturated Porous Materials Using a Flexible Wall Permeameter. ASTM D5084, West Conshohocken, Pennsylvania.

Batu V. 1998. Aquifer Hydraulics: A Comprehensive Guide to Hydrogeologic Data Analysis. John Wiley \& Sons, New York.

Bouwer H. 1989. “The Bouwer and Rice Slug Test - An Update.” Ground Water 27(3):304-309.

Bouwer H and RC Rice. 1976. “A Slug Test for Determining Hydraulic Conductivity of Unconfined Aquifers with Completely or Partially Penetrating Wells.” Water Resources Research 12(3):423-428.

Butler JJ, Jr. 1996. "Slug Tests in Site Characterization: Some Practical Considerations." Environmental Geosciences 3(3):154-163.

Butler JJ, Jr. 1998. The Design, Performance, and Analysis of Slug Tests. Lewis Publishers, CRC Press, Boca Raton, Florida.

Butler JJ, Jr. and EJ Garnett. 2000. Simple Procedures for Analysis of Slug Tests in Formations of High Hydraulic Conductivity using Spreadsheet and Scientific Graphics Software. Open-file Report 2000-40, Kansas Geological Survey, Lawrence, Kansas.

CHPRC (CH2MHill Plateau Remediation Company). 2013. Sampling and Analysis Plan for Perched Water Wells C8914 and C8915 in the 200-DV-1 Operable Unit. DOE/RL-2013-52, Rev. 0, prepared for the U.S. Department of Energy, Richland Operations Office by CH2MHill Plateau Remediation Company, Richland, Washington.

CHPRC (CH2MHill Plateau Remediation Company). 2014. Borehole Summary Report for the Installation of Two Perched Groundwater Wells in the 200-DV-1 Operable Unit in Fiscal Year 2014. SGW-57488, CH2MHill Plateau Remediation Company, Richland, Washington.

Deming D. 2002. Introduction to Hydrogeology. McGraw-Hill Companies, Inc., New York, New York.

Driscoll, FG. 1986. Groundwater and Wells. Johnson Division, St. Paul, Minnesota.

Heath RC. 1983. Basic Ground-Water Hydrology. U.S. Geological Survey Water-Supply Paper 2220, Washington, D.C.

Hyder Z and JJ Butler, Jr. 1995. "Slug Tests in Unconfined Formations: An Assessment of the Bouwer and Rice Technique." Ground Water 33(1):16-22.

Kahleel R. 2007. Far-Field Hydrology Data Package for the RCRA Facility Investigation (RFI) Report. RPP-RPT-35222, Rev. 1, CH2M-Hill Hanford Group, Inc., Richland, Washington. 
Liu WZ and JJ Butler, Jr. 1995. The KGS Model for Slug Tests in Partially Penetrating Wells (Version 3.0). Kansas Geological Survey Computer Series Report 95-1, Lawrence, Kansas.

McElwee CD. 2001. “Application of a Nonlinear Slug Test Model.” Ground Water 39(5):737-744.

McElwee CD and MA Zenner. 1998. "A Nonlinear Model for Analysis of Slug-Test Data." Water Resources Research 34(1):55-66.

Moench AF and PA Hsieh. 1985. "Analysis of Slug Test Data in a Well with Finite-Thickness Skin." In Memoirs Hydrogeology of Rocks of Low Permeability, January 7-12, 1985, Tucson, Arizona. International Association of Hydrogeologists 17(1):17-29.

Newcomer DR. 2008. 300 Area VOC Program Slug Test Characterization Results for Selected Test/Depth Intervals for Wells 399-2-5, 399-3-22, and 399-4-14. PNNL-17439, Pacific Northwest National Laboratory, Richland, Washington.

Reilly TE, OL Franke, and GD Bennett. 1987. The Principle of Superposition and its Application in Ground-Water Hydraulics. U.S. Geological Survey, Techniques of Water-Resources Investigations, Book 3 Applications of Hydraulics, Chapter B6, Reston, Virginia.

Serne RJ, BN Bjornstad, JM Keller, PD Thorne, DC Lanigan, UN Christensen, and GS Thomas. 2010. Conceptual Models for Migration of Key Groundwater Contaminants Through the Vadose Zone and Into the Unconfined Aquifer Below the B-Complex. PNNL-19277, Pacific Northwest National Laboratory, Richland, Washington.

Spane FA, Jr. 1993. Selected Hydraulic Test Analysis Techniques for Constant-Rate Discharge Tests. PNL-8539, Pacific Northwest National Laboratory, Richland, Washington.

Spane FA, Jr. 1996. “Applicability Of Slug Interference Tests for Hydraulic Characterization of Unconfined Aquifer: (1) Analytical Assessment.” Ground Water 34(1):66-74.

Spane FA, Jr. 2007. 300-Area VOC Program Slug Test Characterization Results for Selected Test/Depth Intervals Conducted During the Drilling of Well 399-3-21. PNNL-16732, Pacific Northwest National Laboratory, Richland, Washington.

Spane FA, Jr. and SK Wurstner. 1993. "DERIV: A program for calculating pressure derivatives for use in hydraulic test analysis." Ground Water 31(5):814-822.

Spane FA, Jr and DR Newcomer. 2004. Results of Detailed Hydrologic Characterization Tests FY 2003. PNNL-14804, Pacific Northwest National Laboratory, Richland, Washington.

Spane FA, Jr and DR Newcomer. 2008. Results of Detailed Hydrologic Characterization Tests - Fiscal and Calendar Year 2005. PNNL-17348, Pacific Northwest National Laboratory, Richland, Washington.

Spane FA, Jr and DR Newcomer. 2010a. Slug Test Characterization Results for Multi-Test/Depth Intervals Conducted During the Drilling of CERCLA Operable Unit OU ZP-1 Wells 299-W11-43, 299W15-50, and 299-W18-16. PNNL-19491, Pacific Northwest National Laboratory, Richland, Washington. 
Spane FA, Jr and DR Newcomer. 2010b. Slug Test Characterization Results for Multi-Test/Depth Intervals Conducted During the Drilling of CERCLA Operable Unit OU UP-1 Wells 299-W19-48, 69930-66, and 699-36-70B. PNNL-19482, Pacific Northwest National Laboratory, Richland, Washington.

Springer RK and LW Gelhar. 1991. "Characterization of Large-Scale Aquifer Heterogeneity in Glacial Outwash by Analysis of Slug Tests with Oscillatory Response, Cape Cod, Massachusetts." In: Mallard, GE and Aronson DA (eds.), U.S. Geological Survey Toxic Substances Hydrology Program-Proceedings of the technical meeting, Monterey, California, March 11-15, 1991. U.S. Geological Survey WaterResources Investigations Report 91-4034:36-40.

Todd DK. 1980. Groundwater Hydrology. Second edition, John Wiley \& Sons, New York.

Truex MJ, M Oostrom, KC Carroll, and GB Chronister. 2013. Perched-Water Evaluation for the Deep Vadose Zone Beneath the B, BX, and BY Tank Farms Area of the Hanford Site. PNNL-22449, Pacific Northwest National Laboratory, Richland, Washington.

Williams BA, VJ Rohay, and MH Doornbos. 2012. Path Forward Recommendations Report for the Uranium Contamination in the B Area. SGW-53604, Revision 0, CH2M HILL Plateau Remediation Company, Richland, Washington.

Zurbuchen BR, VA Zlotnik, and JJ Butler, Jr. 2002. "Dynamic Interpretation of Slug Tests in Highly Permeable Aquifers." Water Resources Research 38(3):10.1029/2001WR000354. 


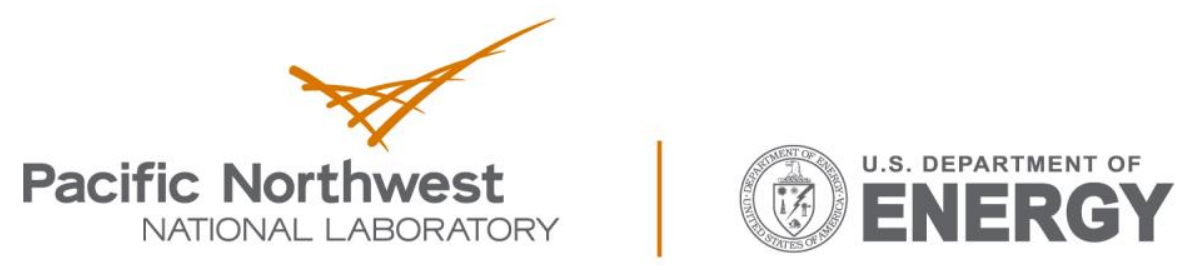

Proudly Operated by Battelle Since 1965

902 Battelle Boulevard

P.O. Box 999

Richland, WA 99352

1-888-375-PNNL (7665)

www.pnnl.gov 